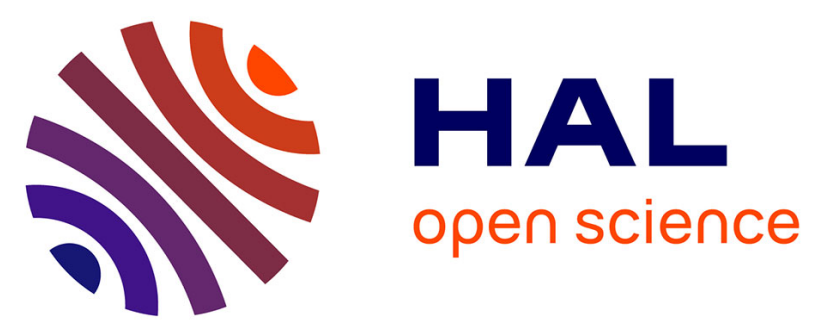

\title{
Zeolites and zeolitization of acid pyroclastic rocks from paroxysmal paleogene volcanism, East Rhodopes, Bulgaria
}

Y. Yanev, J.J. Cocheme, R. Ivanova, O. Grauby, E. Burlet, R. Pravchanska

\section{- To cite this version:}

Y. Yanev, J.J. Cocheme, R. Ivanova, O. Grauby, E. Burlet, et al.. Zeolites and zeolitization of acid pyroclastic rocks from paroxysmal paleogene volcanism, East Rhodopes, Bulgaria. Neues Jahrbuch für Mineralogie - Abhandlungen: Journal of Mineralogy and Geochemistry, 2006, 182 (3), pp.265-283. 10.1127/0077-7757/2006/0050 . hal-00070972

\section{HAL Id: hal-00070972 https://hal.science/hal-00070972}

Submitted on 6 May 2020

HAL is a multi-disciplinary open access archive for the deposit and dissemination of scientific research documents, whether they are published or not. The documents may come from teaching and research institutions in France or abroad, or from public or private research centers.
L'archive ouverte pluridisciplinaire HAL, est destinée au dépôt et à la diffusion de documents scientifiques de niveau recherche, publiés ou non, émanant des établissements d'enseignement et de recherche français ou étrangers, des laboratoires publics ou privés. 


\title{
Zeolites and zeolitization of acid pyroclastic rocks from paroxysmal Paleogene volcanism, Eastern Rhodopes, Bulgaria
}

\author{
Y. Yanev, Sofia, J.J. Cochemé, Marseille, R. Ivanova, Sofia, O. Grauby, E. Burlet, Marseille, \\ and R. Pravchanska, Sofia
}

With 12 figures and 6 tables

\begin{abstract}
An extensive bimodal volcanic suite developed in the Late Paleogene in the Eastern Rhodopes Mountains, Southern Bulgaria. Most of the widespread and thick rhyolitic tuffs and ignimbrites, erupted during two major Early Oligocene acid phases, were emplaced in a shallow marine environment and subsequently altered. K-rich Ca-clinoptilolite (in some places K-clinoptilolite, mordenite or analcime). clay minerals (celadonite or/and smectite). adularia (or albite) and opal-CT replace the volcanic glass. The zeolitized pyroclastic rocks are strongly depleted in $\mathrm{MnO}, \mathrm{Na}_{2} \mathrm{O} . \mathrm{K}_{2} \mathrm{O}$, and enriched in $\mathrm{CaO}, \mathrm{Fe}_{2} \mathrm{O}_{3}, \mathrm{TiO}_{2}$ and $\mathrm{MgO}_{2}$. Regional zoning in distribution of the major glass-replacing minerals has been established: quartz + adularia (or albite) \pm zeolites in the proximal to the vent area: zeolites in the medial and clay minerals in the distal area. Vertical zoning has been also recognized because only the basal pyroclastic layer is transformed into adularia + quartz whereas clinoptilolite. accompanied by opal$\mathrm{CT}$ and clay minerals, prevails in the rest of the section. The zeolitized glass shards are characteristically zoned: (1) a thin rim $(<5 \mu \mathrm{m}$ thick) of celadonite coats the shard surface retaining their original shape: (2) a 30)-50 $\mu \mathrm{m}$-thick zone. made of contiguous platy zeolite crystals, oriented perpendicular to the rim and (3) a central zone of large euhedral crystals. surrounding a central hollow area. Phenocrysts are not affected by the zeolitization and some relict glass is found in the top of the pyroclastic section. According to the semiquantitative X-ray analysis and heat of immersion test of CLI.FAZ et al. (1973) the clinoptilolite content in the zeolitized pyroclastic rocks varies from 38 to $72 \mathrm{wt}$. \%. The cation exchange capacity values range between 40 and $153 \mathrm{meq} /$ $100 \mathrm{~g}$ and show a significant positive correlation with clinoptilolite content obtained by the heat of immersion test $(\mathrm{r}=(0.71)$. The lateral zoning and presence of typical hydrothermal minerals such as celadotite indicate that zeolitization of the thick Eastern Rhodopes pyroclastic series results from the operation of a large low temperature hydrothermal system. The hydrothermal solutions consist of marine water heated by the anomalous geothermal gradient of the active volcanic areas or/and by the hot pyroclastic deposits.
\end{abstract}

Key words: clinoptilolite, ash tuffs. pyroclastic flow deposits, Eastern Rhodopes Mountains. Bulgaria.

\section{Introduction}

During the Paleogene, after the Mesozoic-Cenozoic subduction leading to the closure of the Tethys Ocean. microplates of African origin collided with the southern edge of the Eurasian plate (Ricou 1994). Significant collision-related magmatism (YANEV \& BAHNEVA 1980. YANEV et al. 1998) occurred on the southern edge of the Eurasian plate and resulted in formation of many volcanic areas extending from the Alps to Northwestern Turkey. One of them is Eastern Rhodopes (Southern Bulgaria) where ca. $7000 \mathrm{~km}^{2}$ are now covered by volcanic rocks. The Eastern Rhodopes volcanic association (37 to $25 \mathrm{Ma}$. Lil $\bullet$ et al. 1987) is bimodal. andesite-latitic (locally up to basaltic) and rhyolitic in composition. Intermediate and acid varieties are present in almost equal volumes.

The acid volcanic glass, deposited in marine environment. was transformed into zeolites, mainly clinoptilolite. less mordenite and analcime, accompanied by clay minerals, opal-CT and adularia. In the top of the pyroclastic sections in some places non-zeolitized glass is still preserved (Aleksiev et al. 1997). After the discovery of the zeolitized tuffs (ALEKSIEv 1968) an impres- 

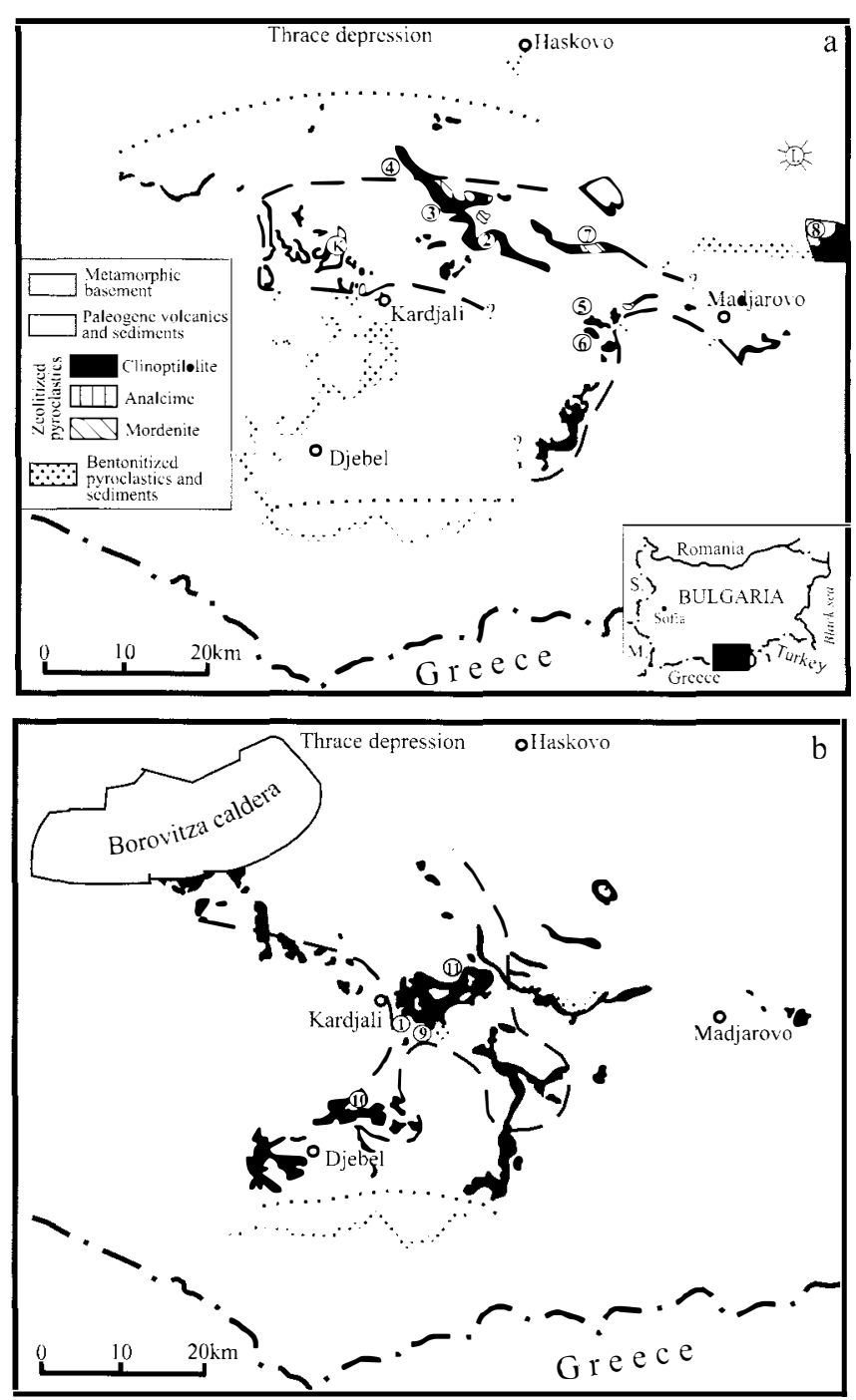

Fig. 1. Distribution of acid pyroclastic rocks from paroxysmal volcanic phases (a: First Early Oligocene acid phase: b: Second Early Oligocene acid phase) in the Eastern Rhodopes (modified from the Geological Map of Bulgaria, 1:100.000), their alteration products (zeolites and clay minerals) and deposits: dashed line indicates limit of distribution of the pyroclastic flows + fall-out tuff's: dotted line indicates limit of distribution of the fall-out tuffs only. Numbers indicate: clinoptilolite deposits - 1. Belia Bair. 2. Most, 3. Gorna Krepost, 4, Beli Plast. 5. Golobradovo, 6. Moriantzi: 7. Liaskovetz mordenite deposit; 8, Sheinovetz caldera (clinoptilolite + mordenite): 9. Jelesni Vrata (quarry): 10. Plazishte and 11. Chiflik outcrops; L. Lozen volcano (Priabonian); K, presumable Kostino volcanic centre and Shabandere section.

sive amount of work on the Eastern Rhodopes zeolitized pyroclastic rocks, dealing with zeolite mineralogy ( $\mathrm{KI}^{-}$ ROV 1974, D.ıurova 1976) and features of some zeolite deposits (Aleksiev \& Diøur@va 1982, Djøur@a \& Aleksiev 1990, Alexiev et al. 1997 and references therein, Raynov et al. 1997. Ivanova et al. 2001), has been published. AlEkSIEv \& DJourova (1975) proposed a geoautoclave hypothesis to explain zeolitisation of the thick pyroclastic series.

A large number of bore-holes were drilled between 1974 and 1982 in the six large economic deposits (Fig. 1) of clinoptilolitized pyroclastics and in one of mordenitized pyroclastics. Beli Plast. Gorna Krepost. Most and Golobradovo belong to the Ist Early Oligocene phase of volcanism. Belia Bair. Jelezni Vrata and the uppermost parts of the Gorna Krepost - to the 2nd phase. The mordenite deposit Liaskovetz belongs to the 1st phase. Actually in exploitation are Beli Plast and Jelezni Vrata. The quantity of the zeolitized material in these deposits varies between some tens to some hundreds of millions of tons. The results of the geological research are summarized in RAYNOV et al. (1997 and references therein).

Despite the impressive literature concerning zeolites from Rhodopes some areas are poorly studied. especially to the northwest and to the south of the town Kardjali where the pyroclastics of the two major acid volcanic phases are widespread (Fig. 1). The aims of our paper are to characterize the zeolitization in some typical geological sections of the paroxysmal acid phases, their morphology, chemistry and quantity of the zeolites. We report the first data on the chemistry of phyllosilicates, accompanying the zeolites and studied the cation exchange capacity (CEC) of the zeolitized pyroclastics and its relation with zeolite contents. We present the lateral and vertical zonality in distribution of glass replacing minerals in the products of the climactic explosive phases and determine the relationship between volcanic environment (proximal, medial or distal zones), type of pyroclastic material and zeolitization. These results combined with already published data allow a better understanding of the zeolitization process of thick acid pyroclastic series in a marine environment.

\section{The products of the acid phases of volcanism}

Several intermediate and acid volcanic phases alternating in time have been distinguished (IvanOV 1963. YANEV et al. 1998). The first two of them (acid and intermediate) are Priabonian. all the others are Rupelian, named 1st. 2nd. 3rd and 4th Early Oligocene phases, respectively. In the Late Oligocene this volcanic activity was followed by dyke intrusion. Here. we report a brief description of the products of the acid phases because only the acid glass is zeolitized (Fig. 1). Bentonitized latitic beds separate the pyroclastics of the acid phases.

The Priabonian acid phase includes the Lozen domevolcano, where no zeolitization had occurred (YANEV et 
al. 1975), and the initial eruptions in the Sheinovetz caldera (IvanOva et al. 2000) (Fig. 1).

The first two, most powerful and voluminous Early Oligocene phases (Fig. 1) were the culmination of the Eastern Rhodopean explosive volcanism. Phase 1 was essentially explosive producing pumice and ash flows accompanied by tephra falls. The volcanic source was probably situated in the region of Kostino village. as inferred from observed progressive decrease in pumice size and deposit thickness away from this area (YANEV 1995, YANEV \& BARDINTZEFF 1996). The products of the flows, weakly to moderately welded ignimbrites and fallout tuffs, cover an area of ca. $65 \times 15-30 \mathrm{~km}$. Their deposition in a marine environment is clearly indicated by the presence of microfossils and underlying coral reefs and marine sediments. Large Priabonian volcanic edifices north and west of the source area restricted the migration of the pyroclastic flows. Only fall-out tuffs were deposited, also subaqueously, further north and westward. To the south of Kostino, the pyroclastic flows reached coastal reefs in the area near the town of Kardjali (Fig. $1 \mathrm{a}$ ). beyond which fall-out tuffs alternate with few $1-2 \mathrm{~m}$-thick limestone beds. Only sediments are deposited in the distal zone - in the southernmost part of Djebel depression (Boyanov \& GoRanov 2001).

The 2nd phase (YANEV \& BaRdintZeFF 1996) is essentially explosive in the northern part of the Eastern Rhodopes, where several large pumice-flow eruptions resulted in Borovitza caldera collapse (Fig. l b). The caldera fill consists of some $\mathrm{km}$ thick succession of strongly welded ignimbrites, accompanied by fall-out tuffs. The outflow units, occupying large areas to the south and east of the caldera, were deposited in a marine environment producing moderately to non-welded ignimbrites. They extend also into the southern part of the Eastern Rhodopes where dome-volcano activity dominated. The total area covered by the pyroclastics of this phase is $c a .80 \times$ $60 \mathrm{~km}$. Only fall-out tuffs were deposited in the medial zone (Djebel depression and eastern part of the Eastern Rhodopes), in some places accompanied by biogenic limestone. Limestone, marl, clay sediments and sandstone. containing dispersed acid pyroclastic material, alternate in the distal zone in the Thrace depression and the southernmost part of Djebel depression (Boyanov \& GoRANOV 2001).

The 3rd Early Oligocene phase is essentially lavic (YANEV 1998): many rhyolitic domes with glassy peripheries were formed both in the northern (Borovitza caldera) and in southern part of the Eastern Rhodopes. A succession of several tens of meters acid pyroclastics and reworked tuffs of unknown volcanic sources has also been assigned to this phase. It is intercalated with muds- tones and sandstones in a $100 \mathrm{~m}$-thick sequence, beginning with a limestone bed. During the 4th phase only one dome-volcano was formed.

\section{Methods}

More than 100 samples from the products of the 1 st and 2nd Early Oligocene acid volcanic phases, collected in the regions to the northwest and to the south of Kardjali town and, for comparison, from the deposits Beli Plast. Jelezni Vrata, Gorna Krepost. Most and Golobradovo. have been studied petrographically in thin sections to elucidate the lateral and vertical zonality in distribution of the glass-replacing minerals.

Twenty three samples richest in zeolites from different geological sections have been selected for further investigations including microprobe analyses. XRD, TEM, and CEC measurements.

- The zeolite composition has been obtained by electron microprobe analysis on the following instruments: $\mathrm{Ca}$ mebax electron microprobe equipped with an X-ray energy dispersive detector (EDX) (using $20 \mathrm{kV}$ acceleration voltage, $10 \mathrm{nA}$ beam current and $7-10 \mu \mathrm{m}$ beam diameter) at the University of Montpelier (samples BU 3 to BU 14): Jeol 870 Superprobe (WDS, using $15 \mathrm{kV}$ acceleration voltage. $10 \mathrm{nA}$ beam current and $10 \mu \mathrm{m}$ beam diameter) at the University of Florence by F. Olmi (samples from Gorna Krepost and Beli Plast deposits); Cameca SX 100 electron mycroprobe (using $15 \mathrm{kV}$ acceleration voltage. $20 \mathrm{nA}$ beam current and $10 \AA$ beam diameter) at the Institute of Petrology of Vienna University (samples 1806 to 1851 and BU21 to BU23).

- The composition of rhyolitic clasts in the lst phase ignimbrites has been analyzed by scanning of an area of $100 \times 100 \mu \mathrm{m}$ using the Jeol 735 Superprobe at Geological Institute, Sofia (analyst Tz. ILyev); the chemistry of glass shards in the 2nd phase ignimbrites at Gorna Krepost deposit - by the Jeol 870 Superprobe at University of Florence (analyst F. OlmI).

- Zeolite accompanying phyllosilicates have been studied by TEM at CRMC2-CNRS. Luminy, Marseille (samples BU 4 to BU 15) and by microprobe at University of Florence (samples from Gorna Krepost deposit).

- The quantity of the mineral phases have been evaluated by semiquantitative X-ray diffraction on a D500 Siemens diffractometer at Geological Institute. Sofia, according to the method of Peter \& Kalman (1964) and Chang (1974, 1975). The operating conditions were: monochromatised $\mathrm{Cu}_{\mathrm{Ka}}$ radiation, $40 \mathrm{kV} .30 \mathrm{~mA}$, continuous scanning at a velocity of $1-2 \% \mathrm{~min}$ using an automatically changeable diaphragm. The quantity of each 


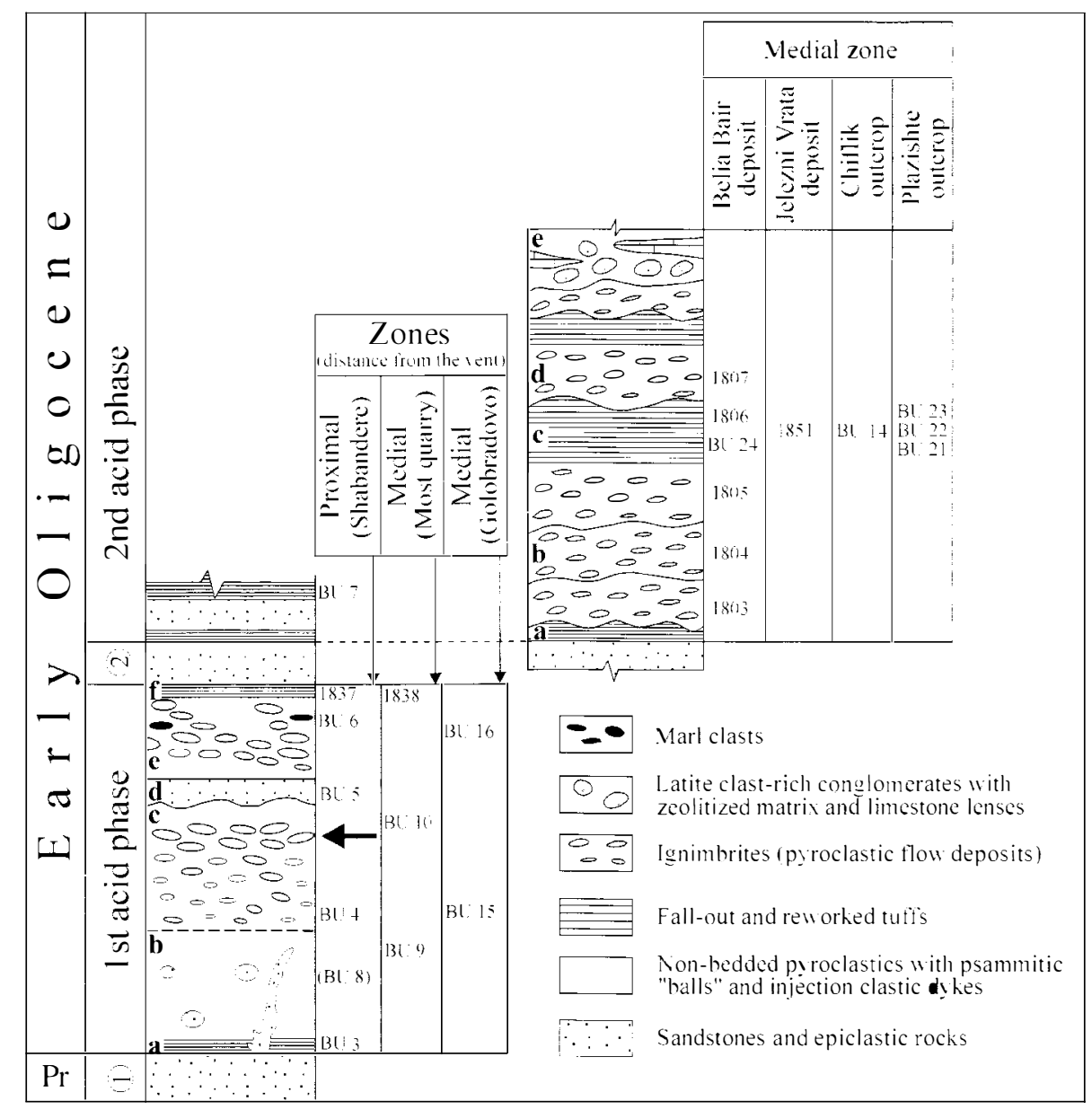

Fig. 2. Schematic lithologic sections (out of scale) of the 1st and 2nd Early Oligocene acid phases showing the position of the samples; a, $\mathbf{b}, \mathbf{c}, \mathbf{d}, \mathbf{e}$ and $\mathbf{f}$ are the lithologic units of 1 st and 2 nd phases described in the text (sample BU 8 belongs also to unit $\mathbf{b}$. but is situated $8 \mathrm{~km}$ to the west of Shabandere section): $\mathbf{1}$ (Pr. Priabonian) and $\mathbf{2}$ indicate epiclastics of the 1 st and 2 nd intermediate phases respectively: the horizontal arrow marks the location of Fig. 3 and the samples from pumice rich upper part of the first pyroclastic flow (Fig. 10).

mineral has been obtained by measuring and calculation of its RIR (reference intensity ratio) where the intensity of corundum (113) peak at $\mathrm{d}=2.085 \hat{\mathrm{A}}$ has been used for comparison. Especially for clinoptilolite the intensity of the peak at $d=3.96 \AA$ has been used.

- The whole-rock analyses have been undertaken using atomic absorption and ICP-AES (analyst M.-O. TRENSZ. CEREGE. France) and by X-ray fluorescence in "Eurotest", Sofia (samples 1803 to 1807).

- The heat of water absorption (heating to $350{ }^{\circ} \mathrm{C}$ ) according to the method of CULFAZ et al. (1973) has been measured at the University of Aix-Marseille-III for obtaining the zeolite quantity and distinguishing clinoptilolite from heulandite.

- For CEC (cation exchange capacity) measurements the ammonium acetate saturation method (Minato 1997). modified by Kitsopoulos (1999), has been followed using Metrohm $692 \mathrm{pH} /$ Ion-Meter (at University of AixMarseille III) with an $\mathrm{NH}_{4}{ }^{+}$-selective gas electrode and precision $\pm 5 \mathrm{meq} / 100 \mathrm{~g}$. P. LEGGO (University of Cambridge. $\mathrm{UK}$ ) has duplicated the CEC measurements.

\section{Studied volcanic sequences}

\section{First Early Oligocene acid phase}

A set of 11 samples was collected from the proximal area of the inferred source (Kostino volcanic center: Fig. 1 a) and from the medial area (Most. Gorna Krepost and Golobradovo deposits situated at 20, 25 and $35 \mathrm{~km}$, respectively. away from the presumable vent). The thickest deposits $(110 \mathrm{~m})$ occur in the Kostino area. where (along the Shabandere stream) the stratigraphic column was 


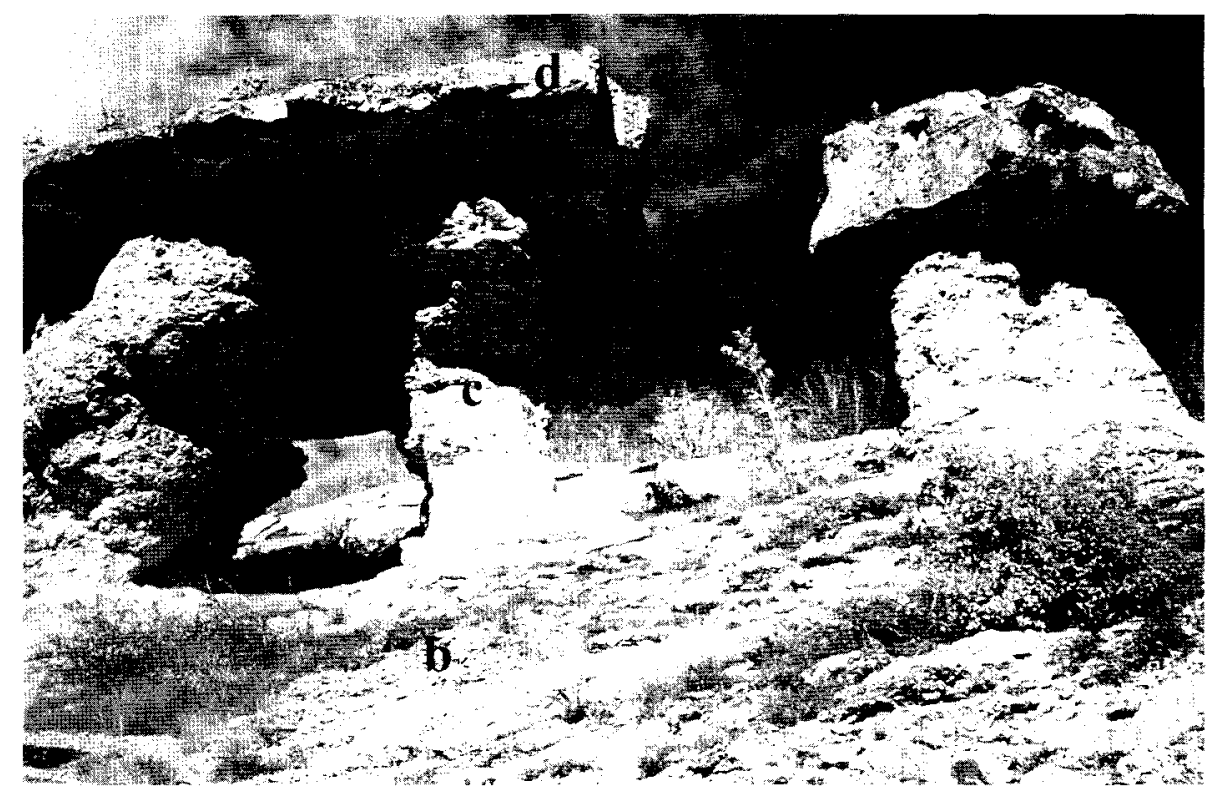

Fig. 3. Northern slop of the Shabandere stream: b, c, d. mark the units of the lst pyroclastic flow (1st Early Oligocene acid phase; see Fig. 2 for location): b, zeolitized lower part and c. strongly adularized upper part of the flow: $\mathbf{d}$, epiclastic bed. The middle column is $\sim 8 \mathrm{~m}$ high.

studied (Fig. 2). There, the acid volcanic pile conformably overlies Priabonian sandstones, siltstones, latitic tuffites. intercalated with one latite flow. Six lithologic units can be distinguished in the 1st phase deposits:

a) Stratified reworked tuffs, hardened by adularisation. lay at the base of the section. They are up to $1-2 \mathrm{~m}$-thick and consist of clast of psammitic size.

b) The following light-green. $40 \mathrm{~m}$-thick massive unit of non-bedded ash pyroclastics, made of acicular glass shards, single crystal clasts and $\mathrm{mm}$-sized pumice fragments (Table 1 - sample BU 3) is interpreted as subaqueous ash flow deposit according to the following characteristics (MCPHIE et al. 1993. CAS \& Wright 1995): large thickness without stratification. texturally unmodified juvenile glassy shards. uniform composition. folded pumice fragments (excluding the cold air-fall deposits), and absence of columnar jointing. The folding of pumice fragments indicates moderate welding. Microfossils (foraminifers, radiolarians), commonly found in the matrix. and coral fragments indicate emplacement in marine environment. Coarse $(\mathrm{cm}$-sized) pumice fragments appear only in the upper part of the unit (sample BU 9 from the Most deposit corresponds to this level). Decimetre-to $-1 \mathrm{~m}$-sized grey or beige "balls" and single injection clastic dykes can be randomly seen. They consist of psammitic sediments with adularia and quartz in the matrix.

c) In the area of Kostino, the top of the first unit grades progressively into $35-40 \mathrm{~m}$ thick moderately welded light-green pyroclastic flow deposits (BU 4) showing broad columnar jointing. This grading is commonly interpreted as indicative of vent proximity (CAS \& WRIGH I 1995). The ignimbrites contain flattened (aspect ratio up to 1:10) yellowish pumice fragments from few $\mathrm{cm}$ in size at the bottom up to $50 \mathrm{~cm}$ at the top. where the rocks are very hardened by the adularisation (Fig. 3). A green ash layer. 10 to $20 \mathrm{~cm}$ thick and interpreted as a coignimbritic air-fall tuff (YANEV 1995. YANEV \& BARDinTZEFF 1996). covers the flow unit. At the Most deposit (BU 10), a set of dm-thick flow units consisting of flattened pumice fragments gives the deposits a rough bedded structure. At the Golobradovo deposit (BU 15), the thickness of the ignimbrite is about $15 \mathrm{~m}$ and the size of the pumice fragments becomes larger toward the top, but do not exceed $20 \mathrm{~cm}$.

d) The fourth unit is a 1 to $8 \mathrm{~m}$-thick cliff-forming layer of well-cemented psammitic to gravel sediments (BU 5) consisting of single tuff fragments. some decimeters in size. enclosed in a matrix of reworked mm-sized shards. Both the fragments and matrix of the sediments are completely zeolitized. At the Golobradovo deposit, this unit ( $1 \mathrm{~m}$ tick) is conglomeratic containing abundant zeolitized pumice and tuff blocks. andesite and metamorphic fragments.

e) This is an alternation of $1-1.5 \mathrm{~m}$ tick beds of fall-out pumice tuff ( $\mathrm{BU}$ 6) and up to $15-20 \mathrm{~m}$ thick ignimbrites rich in flattened pumice clasts. To the East of Shabandere the particular thin flow units integrate into a single 


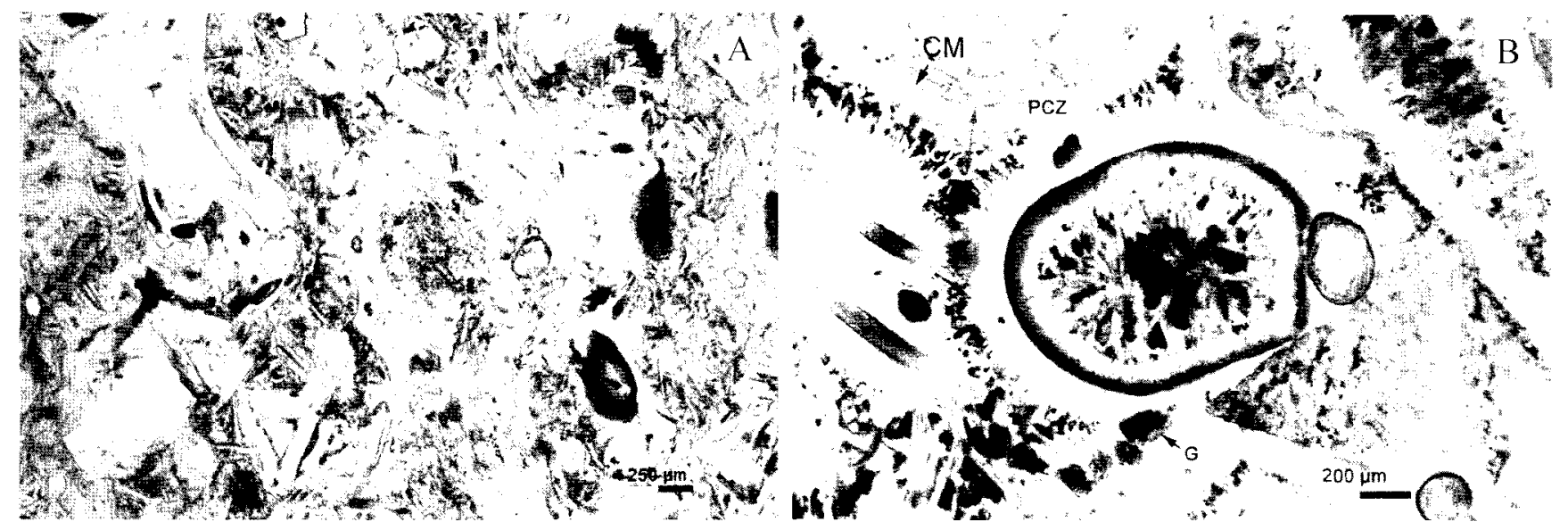

Fig. 4. Photomicrographs showing perfectly preserved original shape of completely zeolitized glass shards (1st volcanic phase): A. sample 1838; B, sample BU5: G and CM - clay minerals. PCZ, and ICZ - platy and idiomorphic clinoptilolite zones, respectively, shown in detail in Fig. 8.

flow deposit that is up to $10 \mathrm{~m}$ thick at the Golobradovo deposit (BU 16). Marl fragments (up to some tens centimeters in size) with thermally metamorphosed margins (some mm thick) are abundant in the upper part of the unit.

f) Well-stratified fall-out tuffs. $5 \mathrm{~m}$ thick (samples 1837 and 1838) form the last unit. The section is capped by the epiclastics and sandstones of the 2 nd intermediatc phase, underlying the fall-out tuffs of the following 2 nd acid phase (BU7).

This section is present also in Most. Gorna Krepost and Golobradovo deposits. At the Beli Plast deposit. located to the north of the area of pyroclastic flows distribution, only vitroclastic and pumice fall-out tuffs are exposed (RAYNOV et al. 1997).

\section{Second Early Oligocene acid phase}

Ignimbrites and fall-out tuffs rich in zeolites have been sampled at four localities in the medial zone. One of the sampled areas is located $25 \mathrm{~km} \mathrm{SE}$ of the Borovitza caldera bounding faults, where Belia Bair and Jelezni Vrata zeolite deposits are situated. Five lithologic units (Fig. 2) have been recognized (YANEV et al. 2004):

a) Layered pale green fall-out tuffs (up to $1 \mathrm{~m}$ thick), covering both the coral reefs and bentonitised latitic tuffs. These fall-out tuffs are disturbed and folded by the overriding pyroclastic flow. They consist of crystal clasts (quartz, feldspars, biotite and amphibole; $0.2-1.2 \mathrm{~mm}$ in size), few lithoclasts (spherulitic rhyolites and perlites). pumices $(0.15-0.6 \mathrm{~mm})$ with spherical bubbles and, occasionally, microfossils. The matrix is made of fine acute glass shards.

b) A set of three pink, non-welded ignimbrites (samples 1803, 1804 and 1805) with a total thickness of ca. $90 \mathrm{~m}$ (RAYNov et al. 1997). They are composed by pumice fragments 1 to $2 \mathrm{~cm}$ in size. crystal clasts $(10-30 \%)$, essentially of quartz and sanidine, and lithoclasts (mostly rhyolites). The lithoclasts are more abundant in the basal flow unit containing also marl xenoliths up to $1 \mathrm{~m}$ in size. These three ignimbrites are separated by thin $(5-10 \mathrm{~cm})$ epiclastic beds with abundant microfossils (Dıourova \& Aleksiev 1990).

c) An 80 m-thick accumulation (RAYNOv et al. 1997) of $\mathrm{cm}$-thick pink fall-out ash tuff layers (sample BU 24, 1806 and 1851). some of which displaying ripple-marks on the bedding planes. Black nodules $(1-2 \mathrm{~cm}$ in diameter) of $\mathrm{Mn}-\mathrm{Ba}$ and $\mathrm{Mn}-\mathrm{Ba}-\mathrm{Si}$ oxide matrix are randomly dispersed in these tuffs. The samples BU 14 (Chiflik outcrop. $25 \mathrm{~km} \mathrm{SE}$ of the caldera border), BU 21, 22 and 23 (Plazishte outcrop, $30 \mathrm{~km}$ south of the caldera border) are from the same unit.

d) The fourth pyroclastic flow unit (sample 1807) is several meters thick and covered by white fall-out tuffs interbedded with thin pyroclastic flow deposits. all petrographically similar to those previously described.

e) Epiclastic sediments, up to $150 \mathrm{~m}$ in thickness, intercalated with reef bodies. They contain rounded $\mathrm{cm}$ to $\mathrm{dm}$ sized latite fragments set in a pink to white matrix of zeolitised shards. 
Table 1. Petrography of the zeolitized Eastern Rhodopes pyroclastic rocks.

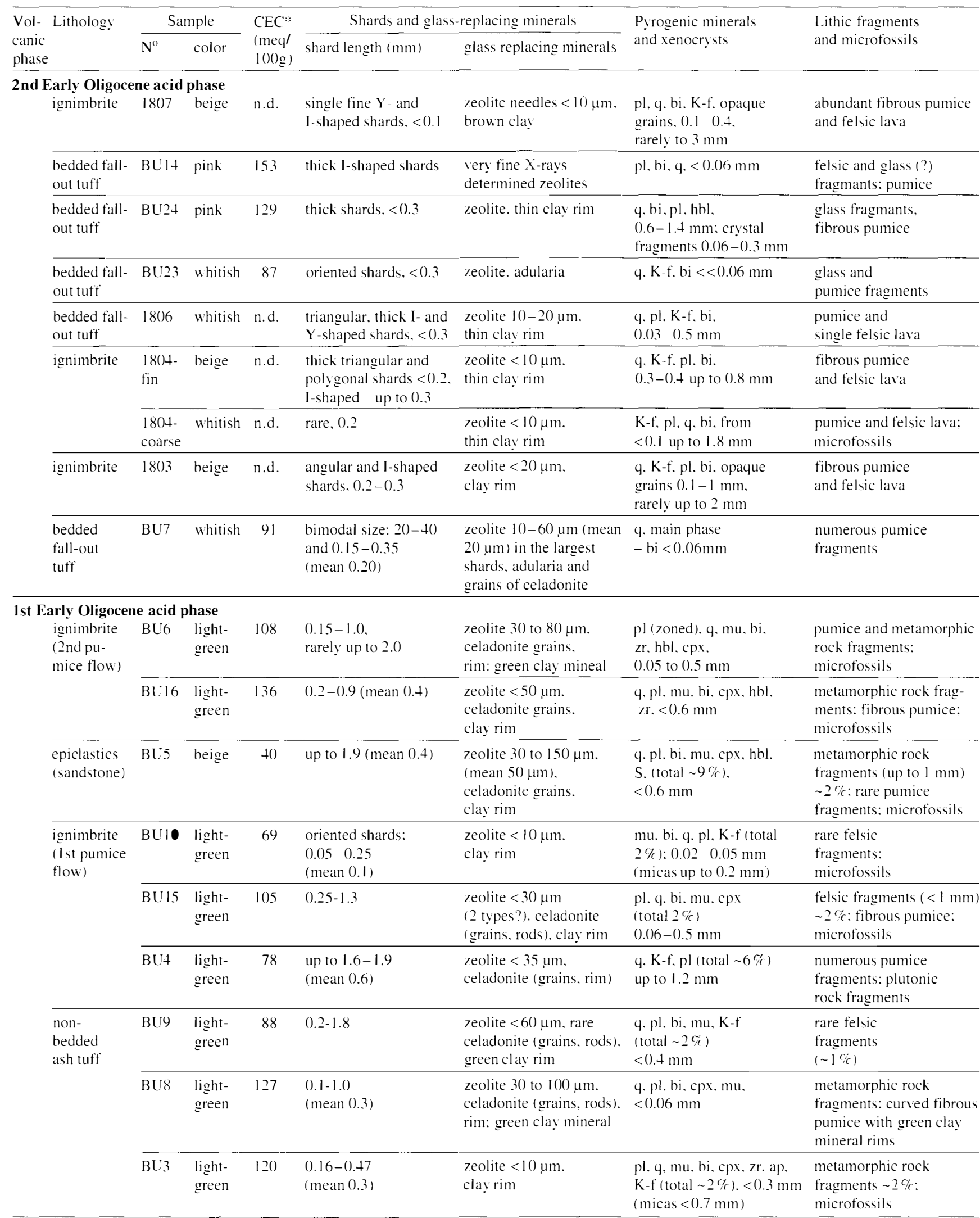

\footnotetext{
* Average of 5 measurements.
}

Pyrogenicminerals (crystalloclasts) and xenocrysts: q. quart7: pl. plagioclase: K-f. K-feldspar: hbl. hornblende: cpx. clinopy roxene: bi. biotite: mu. muscovite: zr, zircon: ap, apatite. 
Table 2. Whole-rock chemical analyses of the zeolitized Eastern Rhodopes pyroclastics and non-zeolitized clasts.

\begin{tabular}{|c|c|c|c|c|c|c|c|c|c|c|c|c|c|c|c|c|c|c|c|c|c|}
\hline \multirow{2}{*}{$\begin{array}{l}\text { Phase } \\
\text { Samples }\end{array}$} & \multicolumn{9}{|c|}{$1 \mathrm{st}$} & \multicolumn{9}{|c|}{ 2nd } & \multirow{2}{*}{\multicolumn{2}{|c|}{$\begin{array}{l}\text { Ist - lithic } \\
\text { clasts: }\end{array}$}} & \multirow{2}{*}{$\begin{array}{l}\text { 2nd - } \\
\text { glass*: }\end{array}$} \\
\hline & $\mathrm{BU}_{3}$ & BL: 8 & $\mathrm{BL}^{\circ} 9$ & BUt & $B U: 15$ & $B L_{10}$ & BU:5 & $\mathrm{BL}^{\circ} 6$ & $\mathrm{BL} 16$ & $\mathrm{BL} 7$ & $\mathrm{BL} 23$ & $\mathrm{BL} 24$ & $\mathrm{BLI}+$ & 1803 & 1804 & 1805 & 1806 & 1807 & & & \\
\hline $\mathrm{SiO}_{2}$ & 67.16 & 67.63 & 67.13 & 66.65 & 67.23 & 69.11 & 68.27 & 65.92 & 66.02 & 65.38 & 61.53 & 65.56 & 68.11 & 73.30 & 73.32 & 73.46 & 70.91 & 70.62 & 77.50 & 73.76 & 71.57 \\
\hline $\mathrm{Al}_{2} \mathrm{O}_{3}$ & 11.63 & 11.66 & 11.26 & 11.75 & 10.97 & 11.33 & 11.86 & 11.45 & 11.12 & 12.70 & 12.08 & 11.55 & 10.18 & $11.1+$ & 11.53 & $10.1+$ & 10.72 & 11.56 & 11.60 & 12.25 & 11.37 \\
\hline $\mathrm{Fe}_{2} \boldsymbol{\bullet}_{3 \mid 01}$ & 0.80 & 0.96 & 0.83 & 1.04 & 0.81 & 0.83 & 1.24 & 0.92 & 1.02 & 0.95 & 1.60 & 0.71 & 0.60 & 1.38 & 1.19 & 0.41 & 0.84 & 1.55 & 0.33 & 0.47 & 0.61 \\
\hline $\mathrm{MnO}$ & 0.01 & 0.04 & 0.01 & 0.06 & 0.0 .3 & 0.01 & 0.12 & 0.05 & (). & 0.02 & 0.01 & 0. & $0.0+$ & 0.01 & 0.00 & 0.01 & 0.04 & (). ()I & 0.08 & 0.11 & .05 \\
\hline $\mathrm{MgO}$ & 0.74 & 0.36 & 0.91 & 1.02 & 0.85 & 0.98 & 1.02 & 0.76 & 0.67 & 1.15 & 0.96 & 0.40 & 0.48 & 0.39 & (0.32 & 0.25 & 0.40 & $0 .+0$ & n.d. & n.d. & 0.11 \\
\hline $\mathrm{CaO}$ & 2.96 & 3.6() & 2.94 & 3.30 & 2.91 & 2.35 & 2.99 & 3.30 & 3.20 & 3.02 & 2.16 & 2.18 & 3.26 & 1.31 & 1.20 & 1.20 & 1.51 & 1.63 & 0.55 & 0.45 & 0.73 \\
\hline $\mathrm{Na}_{2} \mathrm{O}$ & 0.90 & 1.13 & 0.25 & (0.34 & 1.12 & 0.20 & 0.67 & 0.99 & 2.04 & 0.38 & 0.19 & $0 .+3$ & $0 .+9$ & 1.85 & 1.45 & 0.79 & 1.64 & 2.13 & 2.78 & 2.69 & 1.47 \\
\hline $\mathrm{K}_{2} \mathrm{O}$ & 2.80 & 3.23 & 3.49 & 3.35 & 1.80 & +.26 & +.12 & 3.92 & 2.40 & 4.79 & 3.85 & 3.90 & 2.16 & 3.66 & 3.56 & 4.21 & 2.44 & 2.94 & 5.50 & 7.12 & 5.81 \\
\hline $\mathrm{H}_{2} \mathrm{O}$ & 0.70 & 1.02 & 0.71 & 2.28 & 2.47 & 2.27 & 0.57 & 0.51 & 2.69 & 1.97 & 8.13 & 4.74 & 2.11 & n.d. & n. d. & n.d. & n. d. & n. d. & n.d. & n.d. & n. d. \\
\hline $\mathrm{H}_{2} \bullet^{-}$ & 11.27 & 9.66 & $12 .(1) 9$ & 9.99 & 12.10 & 8.84 & 9.09 & 12.44 & 10.89 & 9.38 & 9.53 & 9.98 & 11.59 & 5.95 & $5.6 t$ & 8.48 & 10.62 & $8.1+$ & n. d. & n.d. & n.d. \\
\hline Total & 99.15 & 99.47 & 99.79 & 100.03 & 100.47 & 100.35 & 100.18 & 100.45 & 100.27 & 99.96 & 100.23 & 99.62 & $99.1+$ & 99.13 & 98.34 & 99.05 & 99.22 & 99.13 & 98.34 & 96.97 & 91.12 \\
\hline
\end{tabular}

* Average microprobe analyse of two type of lithic clasts in the /eolitiod ignimbrites of the Ist phase - Most quarry (number of analyses 2 and 5 respectively 1.

s. Average microprobe analyse of glass shards in the zeolitized ignimbrites of the 2nd phase - Gorna Krepost deposit (number of analyses 5 )

\section{Results}

\section{Petrographic and chemical composition of the zeolitized pyroclastics}

All studied samples are zeolite rich and their petrography and mineralogy are summarized in Table 1.

The fall-out tuffs as well as the matrix of the ignimbrites are vitroclast rich and consist of arcuate, rod-like, crescent-shaped, triangular shards with concave sides (Fig. 4). The rocks contain also pyrogenic (mostly quartz, less sanidine, plagioclase and biotite, rarely amphibole. clinopyroxene and some accessories such as magnetite, apatite, zircon, titanite) and xenogenic minerals probably derived from the metamorphic basement (mosaic quartz, K-feldspar, muscovite). Pumice (with tube-like and spherical vesicles), massive lithic clasts (spherulitic or felsitic rhyolite and perlite), some microfossils. fragments of limestone, latitic and metamorphic rocks are also present. The ignimbrites are very rich in pumice clasts, varying in size. In the 1st phase ignimbrites they are strongly flattened (see above) while in the ignimbrites of the 2 nd phase the pumice clasts are not deformed.

The major and trace element distribution in the zeolitized pyroclastic rocks is presented in Tables 2 and 3 . The zeolitized ignimbrites of the 2nd phase (Belia Bair deposit) are richer in $\mathrm{SiO}_{2}$ due to their high quartz and lithic clasts contents (Table 1). A comparison between two types of rhyolitic clasts (according to their $\mathrm{K}_{2} \mathrm{O}$ content) from the 1st phase, and between non-altered glass shards of the 2nd phase from Gorna Krepost deposit and zeolitized pyroclastics of the same phase. respectively, is shown in Fig. 5. The change in $\mathrm{SiO}_{2}$ and $\mathrm{Al}_{2} \mathrm{O}_{3}$ contents is minor, but the zeolitized samples are strongly depleted in $\mathrm{MnO}, \mathrm{Na}_{2} \mathrm{O}$ and $\mathrm{K}_{2} \mathrm{O}$ (i. e. these oxides are partly

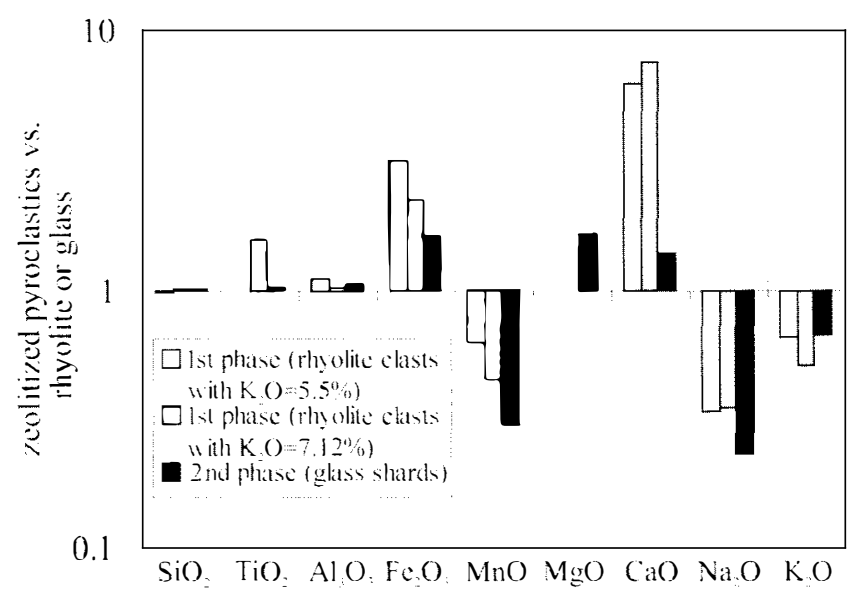

Fig. 5. Difference in major element composition between the studied zeolitized pyroclastic rocks and unaltered rhyolitic clasts (two types with different $\mathrm{K}_{2} \mathrm{O}$ content) of the 1st phase and unaltered glass shards of the 2nd phase (anhydrous base: see Table 2).

leached), and enriched in $\mathrm{CaO}, \mathrm{Fe}_{2} \mathrm{O}_{3} . \mathrm{TiO}_{2}$ and $\mathrm{MgO}$. In the altered pyroclastics $\mathrm{CaO}$ is incorporated in zeolites and the other three oxides in phyllosilicates.

The average LILE contents in the zeolitized pyroclastics have a tendency to increase from the 1 st to the 2 nd phase (Rb from 214 to $222 \mathrm{ppm}$; Sr from 286 to 409 ppm: Ba from 88 to $170 \mathrm{ppm}$ ). HFS elements are immobile during the zeolitization and the $\mathrm{Nb} / \mathrm{Zr}$ ratio (Fig. 6) shows that the zeolitized rocks have their primary magmatic (collisional) signatures still preserved.

\section{Glass-replacing authogenic minerals}

All of the glassy volcaniclastic fragments (shards and pumice) are completely altered but their original shape is 
Table 3. Trace element content in the Eastern Rhodopes zeoitized pyroclastics (in ppm).

\begin{tabular}{|c|c|c|c|c|c|c|c|c|c|c|c|c|c|}
\hline \multirow{2}{*}{$\begin{array}{l}\text { Phase } \\
\text { Sample } N^{\circ}\end{array}$} & \multicolumn{9}{|c|}{$1 \mathrm{st}$} & \multicolumn{4}{|c|}{$2 \mathrm{nd}$} \\
\hline & $\mathrm{BU} 3$ & BU 8 & BU9 & $\mathrm{BU} 4$ & BU 15 & BU 10 & $\mathrm{BL} 5$ & BU6 & $\mathrm{BU} 16$ & $\mathrm{BU} 7$ & $\mathrm{BU} 23$ & $\mathrm{BU} 24$ & $\mathrm{BU} 14$ \\
\hline $\mathrm{Rb}$ & 238 & 231 & 249 & 197 & 166 & 218 & 198 & 231 & 201 & 237 & 208 & 267 & 177 \\
\hline $\mathrm{Sr}$ & 634 & 91 & 72 & 283 & $9(07$ & 107 & 118 & 103 & 256 & 317 & 211 & 152 & 955 \\
\hline $\mathrm{Ba}$ & 262 & 111 & 44 & 39 & 64 & 61 & 84 & 47 & 84 & 238 & 152 & 102 & 191 \\
\hline $\mathrm{Cu}$ & 3 & 4 & 1 & 3 & 2 & 1 & 4 & 2 & 1 & 3 & 4 & 2 & 2 \\
\hline $\mathrm{Cr}$ & 12 & 6 & 4 & 8 & 6 & 4 & 12 & 3 & 3 & 3 & 6 & 6 & 2 \\
\hline $\mathrm{Ni}$ & 4 & 6 & 1 & 1 & 1 & 2 & 7 & 3 & 4 & 4 & 6 & 1 & 1 \\
\hline $\mathrm{V}$ & 16 & 13 & 14 & 4 & 12 & 11 & 12 & 10 & 13 & 15 & 14 & 13 & 11 \\
\hline $\mathrm{Zn}$ & 38 & 34 & 30 & 35 & 30 & 27 & 37 & 33 & 45 & 44 & 42 & 21 & 21 \\
\hline $\mathrm{Zr}$ & 130 & 130 & 115 & 134 & 127 & 115 & 148 & 137 & 124 & $1+1$ & $1+1$ & 86 & 104 \\
\hline Y & 19 & 21 & 25 & 18 & 18 & 24 & 29 & 25 & 21 & 24 & 20 & 4 & 3 \\
\hline $\mathrm{Nb}$ & 18 & 20 & 19 & 23 & 18 & 19 & 23 & 23 & 22 & 23 & 15 & 14 & 8 \\
\hline
\end{tabular}

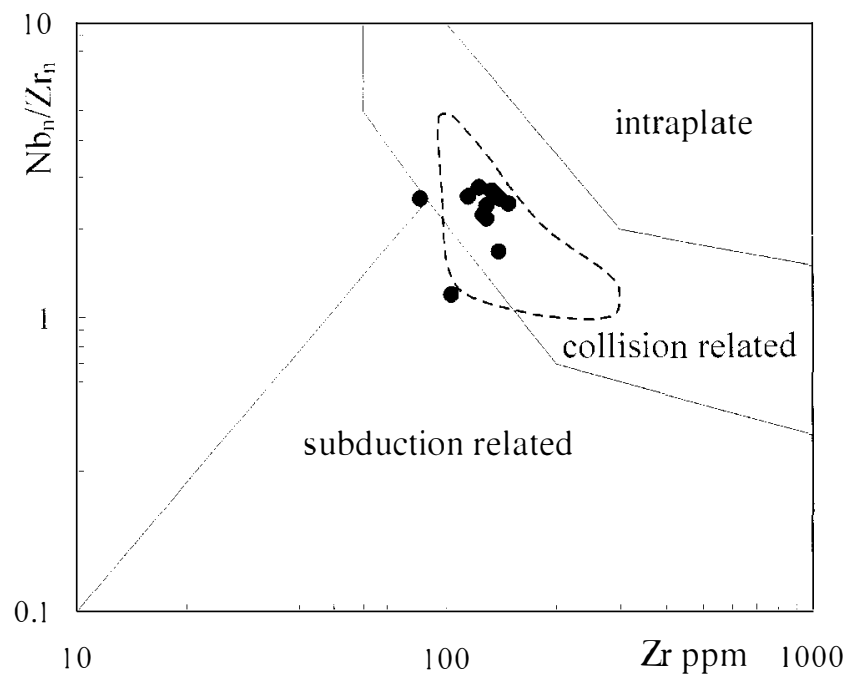

Fig. 6. $\mathrm{Nb}_{\mathrm{n}} / \mathrm{Zr}_{\mathrm{n}}$ vs. $\mathrm{Zr}$ diagram (according to ThIeblemont \& TeGYEY 1994: normalizing factors: $\mathrm{Nb}-(0.6175 . \mathrm{Zr}-9.713)$. showing the geodynamic setting of the zeolitized pyroclastic rocks (dashed line shows the field of the Eastern Rhodopes acid volcanics after YANEV 1998).

commonly well preserved (Fig. 4). The glassy shards in the matrix of the epiclastic layers are also altered. Only in few places in the topmost parts of the 2 nd phase sequence up to $50 \%$ of glass is unaltered (ALEKSIEv et al. 1997). The crystal clasts (sanidine, plagioclase, and biotite) are not affected by the zeolitization.

The glass-replacing mineral association consists of zeolites, phyllosilicates, feldspars and opal-CT. The quantitative estimations (Fig. 7) have shown that clinoptilolite is the most abundant mineral (38 to $72 \mathrm{wt} . \%$ ). The zeolitized pyroclastics of the 2 nd phase have lower clinoptilolite content than those of the 1st one.
Zonal arrangement of the glass shards-replacing phases is typical of the studied samples as up to 3 concentric zones have been observed from the periphery to the centre of the shards (Figs. 4 and 8): (1) a thin $\operatorname{rim}(<5 \mu \mathrm{m}$ thick) of green clay minerals coat the shard surface retaining their original shape; (2) a 30-50 $\mu \mathrm{m}$-thick zone, made of contiguous platy and colorless zeolite crystals oriented perpendicular to the rim; (3) a central zone of large euhedral and frequently pink zeolite crystals. usually surrounding a central hollow area. Sometimes opal-CT is found in the centre of the shards, between the large zeolite crystals.

Zeolites from the shards were analyzed in 20 samples from different localities. stratigraphic levels and zeolite deposits (for comparison). The zeolites have been defined as clinoptilolites (Table 4) since their $\mathrm{Si} / \mathrm{Al}$ ratio is $>4$ (CoOMBS et al. 1997). According to the extra framework cation distribution (Fig. 9) most of the analyzed zeolites are $\mathrm{K}$-rich $\mathrm{Ca}$-clinoptilolites. The fine clinoptilolite crystals grown on vesicle walls in pumice from the lower pyroclastic flows of the 2nd phase (Belia Bair deposit) are potassic (YANEv et al. 2004). An evident decrease in potassium contents upward coupled with an increase of $\mathrm{Ca} . \mathrm{Mg}$ and especially $\mathrm{Na}$ has been detected in clinoptilolite from this deposit. In one sample (from Shabandere section, 1st phase) the zeolites of the colorless rim of the glassy shards ( $\mathrm{BC} 4$ a) are richer in $\mathrm{Mg}$ and have a lower $\mathrm{Ca}$ content than the central pink zone (BU 4 b).

By applying the heat of immersion test of Culfaz et al. (1973) to some of the samples, values of $\Delta \mathrm{T}$ between 5.4 and $8.9^{\circ} \mathrm{C}$ have been obtained after heating at $350^{\circ} \mathrm{C}$. One of the samples of 2 nd phase (BU 14) has been tested at $450{ }^{\circ} \mathrm{C}$ and its $\Delta \mathrm{T}$ varies slightly from 8.8 to $8.3^{\circ} \mathrm{C}$. This result suggests that no heulandite s. $s$. (heulandite type I of Alietri et al. 1977) is present in the samples 


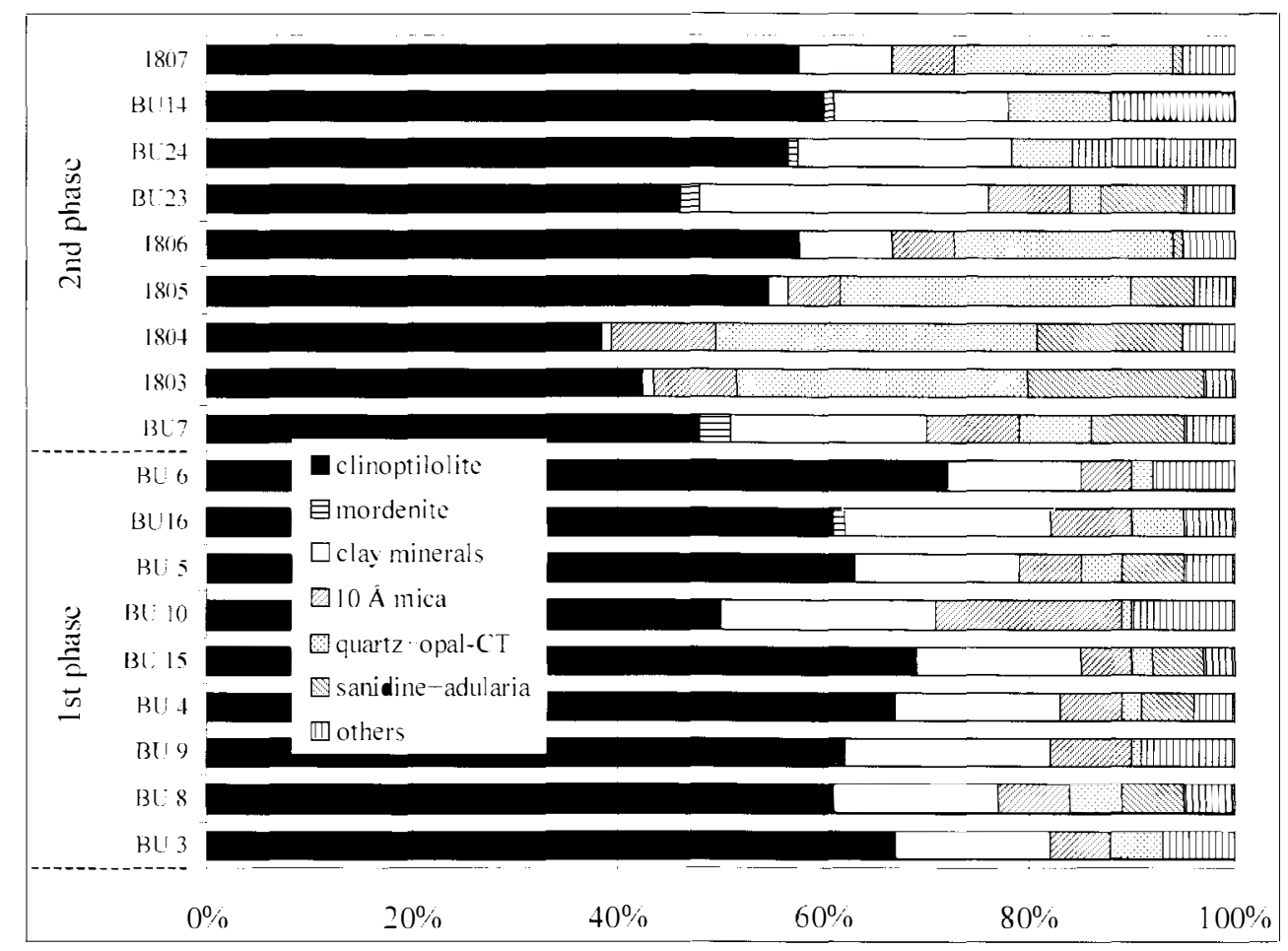

Fig. 7. Modal amount of the pyrogenic and authogenic minerals replacing glass in the zeolitized pyroclastics from Eastern Rhodopes (estimation by XRD analysis): "others" includes plagioclase. biotite. amphibole. clinopyroxene. muscovite, accessories. For sample location see Fig. 2.

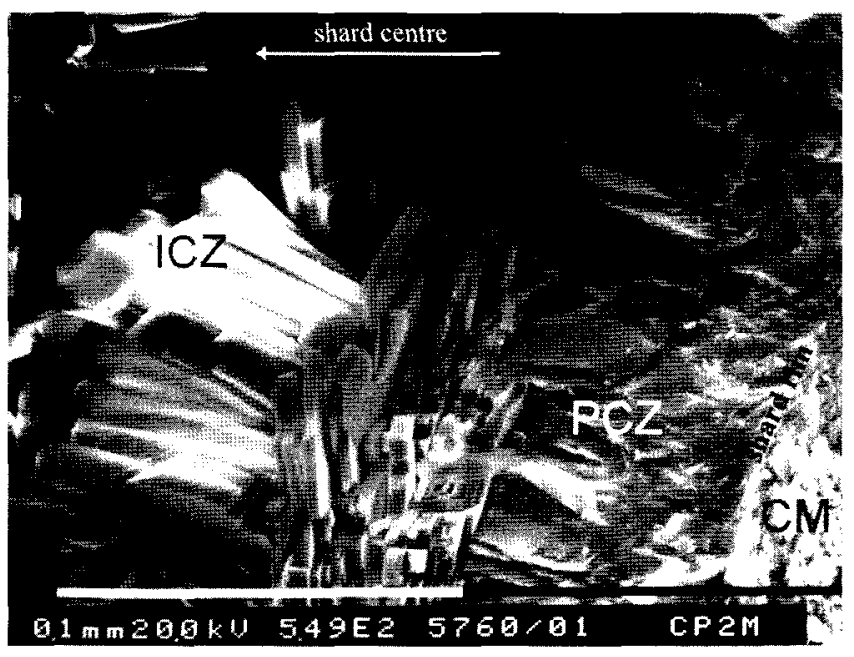

Fig. 8. SEM image showing details of a zeolitized glass shard (sample BU5, the Shabandere section, for location of the zones see Fig. 4 b): thin clay-coating film at the shard rim (CM. lower right). a zone of platy clinoptilolite crystals (PCZ) and idiomorphic clinoptilolite crystals (ICZ) towards the centre of the shard. The white scale bar corresponds to $0.1 \mathrm{~mm}$.

studied. Heated to such temperatures. it undergoes complete destruction (e. g. heulandite from Deccan plateau. India according to the our mesurments has $\Delta \mathrm{T}=$

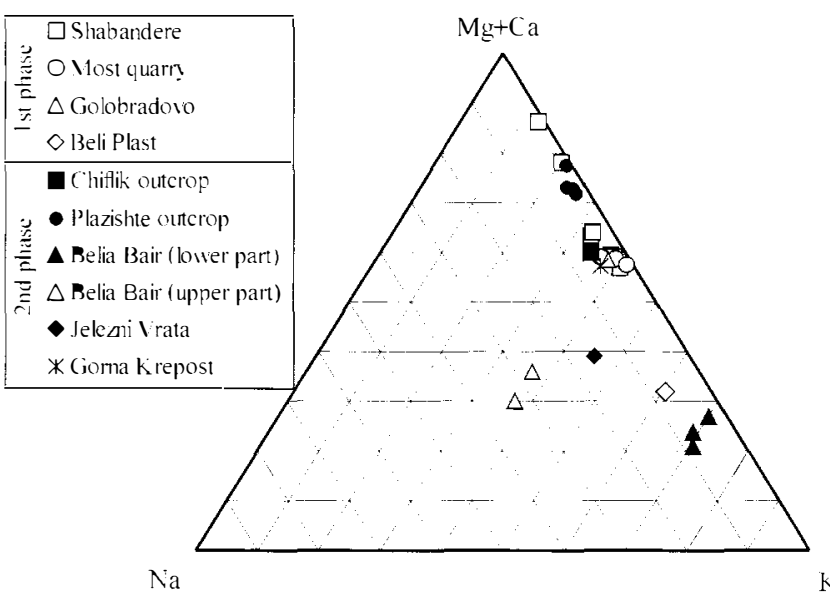

Fig. 9. Extra framework cations in clinoptilolites from zeolitized pyroclastic rocks of both Ist and 2nd volcanic phases: for data see Table 4. locations in Fig. 1.

$0.44^{\circ} \mathrm{C}$ ). The quantities of the clinoptilolite determined by this method are close to those determined by X-ray diffraction ( $\pm 15 \%$ in some samples). The maximum clinoptilolite content obtained by this method (Table 5) has been found in the fine ash matrix of the uppermost py- 
Table 4. Average microprobe analyses of clinoptilolite and calculated formulae (based on the 72 oxigens).

\begin{tabular}{|c|c|c|c|c|c|c|c|c|c|c|c|c|c|c|c|c|c|c|c|c|c|c|c|}
\hline \multirow{2}{*}{$\begin{array}{l}\text { Phase } \\
\text { Sample }\end{array}$} & \multicolumn{12}{|c|}{ Ist } & \multicolumn{11}{|c|}{ 2nd } \\
\hline & BL18 & BLta & $\mathrm{BU}+\mathrm{b}$ & BU5 & BU!6 & $18.37-1$ & $18.37-2$ & $\mathrm{BL} 9$ & $\mathrm{~B} \cup 10$ & 18.38 & \multirow{2}{*}{$\frac{\text { BC15 }}{\text { (iol) }}$} & \multirow{2}{*}{$\begin{array}{l}\text { Beli } \\
\text { Plast }\end{array}$} & L1t & $B L 2=1$ & $\mathrm{BL} 22-1$ & BL'2?-2 & $\mathrm{BL} 23$ & $180+1$ & $180+4-?$ & 1806 & 1807 & \multirow{2}{*}{$\frac{1851}{\text { J. Vratta }}$} & \multirow{2}{*}{$\begin{array}{l}\text { Gornat } \\
\text { Krepost }\end{array}$} \\
\hline \multicolumn{2}{|l|}{ Locality } & \multicolumn{6}{|c|}{ Shabandere section } & \multicolumn{3}{|c|}{ Most } & & & \multicolumn{5}{|c|}{ Chitlik and Plazishte outcrops } & \multicolumn{4}{|c|}{ Belial Bair deperit } & & \\
\hline $\mathrm{SiO}_{2}$ & 66.96 & 67.27 & 65.57 & 67.35 & 66.81 & 65.13 & 65.15 & 67.03 & 67.61 & $66.2++$ & $67.8 .+$ & $68.1 .+$ & 69.35 & 66.92 & $6+1+10$ & 65.82 & 68.99 & $66.8+$ & 62.31 & 62.38 & $(2+.95$ & $6+43$ & 68.33 \\
\hline $\mathrm{Al}_{3} \mathrm{O}_{3}$ & 11.29 & 12.28 & 12.64 & 12.12 & 11.51 & 12.29 & 12.43 & 11.50 & 11.90 & $11.7+4$ & 11.80 & 11.98 & 11.77 & 11.95 & 12.20 & 12.16 & 11.72 & 12.22 & $11 .+5$ & 11.85 & 12.31 & 1195 & 11.89 \\
\hline $\mathrm{Fe}_{2} \mathrm{O}_{3 t \mathrm{n}}$ & 0.08 & 0.12 & 0.17 & 0.11 & 0.07 & 0.09 & (). 10 & 0.07 & 0.08 & 0.24 & 0.08 & 0.03 & 0.08 & 0.11 & 0.13 & 0.06 & $0.20)$ & $0.0 .+$ & 0.03 & (0.05 & 0.04 & 0.0 .3 & 0.46 \\
\hline $\mathrm{MgO}$ & (0.70) & (1).90) & $0.4+$ & 0.69 & 0.76 & 0.92 & 0.99 & 0.72 & 0.62 & 0.70 & 0.59 & 0.05 & 0.33 & 0.67 & & (0.89 & 0.61 & 0.24 & 26 & 0.33 & 0.39 & 0.35 & 1.08 \\
\hline a) & 3.26 & 3.83 & 7 & 3.4 .4 & 3.26 & & 4.76 & 3.29 & 3.53 & 3.50 & 3.51 & 2.40 & $3.8+$ & t. & & & +.26 & 2.07 & 3 & 3.32 & 1.89 & 2.61 & 2.9() \\
\hline $\mathrm{Ni}_{2} \mathrm{O}_{2}$ & 0.15 & 0.30 & 0.25 & 0.18 & 0.17 & 1) & 0.07 & 0.15 & 0.31 & 0.08 & 0.25 & 0.57 & 0.40 & 0.1 & 0.0 .5 & (0.14 & 0.20 & 0.26 & 0.59 & 1.99 & 2.40 & 1.17 & 0.39 \\
\hline $\mathrm{K}_{2} \mathrm{O}$ & 2.60 & 2.4 .4 & 2.4 .4 & 2.97 & 2.58 & 1.35 & 0.84 & 2.67 & 2.56 & $3 .(1) 2$ & 2.65 & +.61 & 2.39 & 1.7 & $1 .+3$ & 1.69 & 1.58 & 6.04 & 5.78 & 2.71 & 280 & 3.44 & 2.59 \\
\hline $\mathrm{H}_{2} \mathrm{O}_{\mathrm{tu}, \mathrm{t}}$ & 14.96 & 12.86 & $1+.12$ & $13.1+$ & $1+.8 .4$ & 15.83 & 15.66 & 14.57 & 13.39 & $1+.+8$ & 13.28 & 12.22 & $11.8+$ & $1+.35$ & 16.56 & 15.210 & 12.44 & 12.29 & 17.85 & 18.37 & 15.22 & 16.02 & 12.36 \\
\hline$n$ & 9 & 12 & 7 & 15 & 9 & 12 & 19 & 13 & 5 & 16 & 4 & 2 & & 13 & 12 & 11 & 21 & 2 & 15 & 3 & 1 & 8 & \\
\hline Si & 30.07 & 29.40 & 29.35 & 29.75 & 29.97 & 29.49 & 29.39 & 29.99 & 29.87 & 29.77 & 29.93 & 29.87 & 30.06 & 29.79 & 29.45 & $29.60)$ & 29.99 & 29.71 & 29.6 .4 & $29 \ldots 7$ & 29.52 & 29.61 & 29.83 \\
\hline Al & 5.98 & 6.63 & 6.67 & 6.30 & $6 .(19)$ & 6.55 & 6.61 & 6.077 & 6.19 & 6.19 & 6.1 .3 & 6.19 & 6.01 & 6.26 & 6.58 & 6.45 & 6.00 & 6.40 & 6.42 & $6.60)$ & 6.60 & 6.48 & 6.12 \\
\hline $\mathrm{Fe}^{3 .}$ & 0.0 .3 & 0.04 & 0.07 & 0.04 & 0.02 & 0.03 & 0.04 & 0.02 & 0.0 .3 & 0.09 & 0.03 & 0.01 & 0.0 .3 & 0.04 & 0.05 & (0.02 & 0.07 & 0.01 & 0.01 & 0.02 & 0.02 & 0.01 & 0.17 \\
\hline $\mathrm{Mg}$ & 0.47 & 0.59 & 0.30 & 0.45 & 0.5 & 0.6? & 0.67 & (1).49 & 0.41 & 0.47 & 0.39 & 0.32 & 0.21 & ) & (). & 0.60 & 0.40 & 0.15 & 0.18 & 0.23 & 0.26 & $0.2+t$ & 0.71 \\
\hline $\mathrm{Ca}$ & 1.57 & 1.79 & 2.10 & 1.6 .3 & 1.57 & (1) & 2.30 & 1.58 & 1.67 & 1.68 & 1.66 & 1.22 & 1.78 & 1. & 2.11 & . & 1.98 & (1).99 & 0.88 & 1.18 & (0.9? & 1.29 & 1.35 \\
\hline $\mathrm{Na}$ & 0.1 .3 & 0.25 & (0.22 & 0.15 & (0).15 & 0.08 & 0.06 & 0.12 & (0. 26 & 0.07 & 0.21 & 0.48 & 0.34 & (). & 0.05 & 0.12 & 0.16 & (0. 2.3 & 0.55 & 1.83 & 2.11 & 1.0.t & $0.3 .+$ \\
\hline $\mathrm{K}$ & 1.49 & 1.36 & 1.39 & 1.67 & 1.48 & 0.78 & 0.48 & 1.52 & 1.44 & 1.73 & 1.19 & $2 .+4)$ & 1.32 & 0.97 & 0.84 & 0.97 & 0.88 & 3.3 .7 & 3.51 & 1.6 .3 & 1.62 & ?.(1)? & 1.43 \\
\hline Totil & 39.74 & .40 .06 & $4(1) .10$ & 39.99 & 39.79 & 39.6 .4 & 39.55 & 39.79 & 39.87 & 40.00 & 39.84 & $40 .+4$ & 39.75 & 39.60 & (9.11) & 39.71 & 39.48 & 40.83 & +1.19 & .40 .96 & +1.05 & 40.69 & 39.95 \\
\hline $\mathrm{Si} / \mathrm{Al}$ & 5.03 & & & $1.1-$ & & & & 4.94 & 4.8 .3 & & & 4.83 & & & & & 5.00 & .7.6t & $+6 ?$ & $4 .+7$ & t.7.1 & $+\cdots$ & 4.87 \\
\hline E\% & 5.4 .4 & 4.71 & 5.15 & $6 .(1) 2$ & 5.5 .3 & 4.78 & 2.62 & 5.36 & 6.1.7 & 2.95 & 6.21 & +03 & 7.09 & 6.42 & 4.41 & 4.52 & 4.66 & 9.57 & t.05 & $5 .+1$ & 8.70 & 6.05 & 6.79 \\
\hline
\end{tabular}

BLt - alverage analyses of the shard rim (a) and central fone (b): numbers 1 and 2 (in BU22. 1804 and 18.37 ) indicate fine and coarse samples respectivels. Zeolite deposits a for compartisons: Golobratdovo (Gol.). Beli Plast. Belia Bair. Jelezni Vratta (J. Vratti). Gorna K'repost (uppermost part of the deposit)

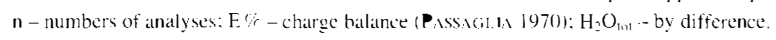

Table 5. Comparison of the clinoptilolite content (wt. \%) determined by heat of immersion and X-ray diffraction.

\begin{tabular}{|c|c|c|c|c|c|c|c|c|c|c|c|c|c|}
\hline \multirow{2}{*}{$\begin{array}{l}\text { Phase } \\
\text { Sample No }\end{array}$} & \multicolumn{9}{|c|}{$1 \mathrm{st}$} & \multicolumn{4}{|c|}{ 2nd } \\
\hline & BU 3 & BU 4 & BU 5 & BU 6 & BU 8 & BU9 & BU 10 & BU 15 & $\mathrm{BU} 16$ & BU 7 & BU 14 & $\mathrm{BU} 23$ & $\mathrm{BU} 24$ \\
\hline Heat of immersion & 63 & 62 & 41 & 71 & 57 & 63 & 61 & 69 & 66 & 44 & 69 & 46 & 47 \\
\hline $\mathrm{X}$-ray diffraction & 67 & 67 & 63 & 72 & 61 & 62 & 50 & 69 & 61 & 48 & 60 & 46 & 57 \\
\hline
\end{tabular}

roclastic flow unit of the 1st phase (BU6), and the lowest in one of the 2 nd phase flow units (sample 1804) which is very rich in crystal and lithic clasts.

Tiny needles of mordenite, in association with adularia, have been observed by SEM in pumice from top of the lower ignimbrite unit of the 1st volcanic phase (Fig. 10). The X-ray data indicate that small amounts of mordenite are present in some samples (Fig. 7).

Phyllosilicates are present as green rims around the shards, essentially in the 1st phase (Fig.4) as well as isolated brown or green-colored grains or clusters (average size of $40 \mu \mathrm{m}$ ) within the internal clinoptilolite zones. Based on X-ray studies two minerals have been identified, a swelling one (smectite) and a mica-like mineral (celadonite). The microprobe analyses (Table 6, Fig. 11) of the green-colored grains and clusters in the pyroclastics of the 1st phase correspond to glauconite. Celadonite and celadonite-smectite mixed layer species (probably with prevailing celadonite layers) are present in the zeolitized pyroclastics of both phases. It is possible that some of the clays plot in the field of glauconite because their total iron has been expressed as $\mathrm{Fe}^{3+}$.
Feldspars. Near the presumable volcanic centre of the 1st phase (in the Shabandere section), adularia, accompanied by small needles of mordenite (Fig. 10 left), is the most abundant authigenic mineral in the pumice clasts in the topmost parts of the 1st pyroclastic flow unit (Fig. 3). Clinoptilolite, associated with adularia, prevails in the matrix (Fig. 10 right). Albite has been also (but rarely) identified in the largest pumice blocks. Adularia and quartz are the most abundant authigenic phases in the matrix of the "balls" and in the injection clastic dykes in the pyroclastic rocks of the 1st phase as well as in the basal layers of the section in the whole proximal and medial areas.

\section{Cation Exchange Capacity (CEC)}

CEC is an essential characteristic that determines the zeolitized pyroclastics as industrial material used for different purposes. CEC of 14 samples (13 from the studied area. Table 1, and one for comparison from the Beli Plast 
Table 6. Electron microprobe analy ses of phyllosilicates and calculated formulae (based on the 11 oxigens as $\mathrm{H} 2 \mathrm{O}$ has not been considered).

\begin{tabular}{|c|c|c|c|c|c|c|c|c|c|c|c|c|c|c|c|c|c|c|}
\hline \multirow{3}{*}{$\begin{array}{l}\text { Volcanic phase } \\
\text { Vo sample } \\
\text { No atnalysis }\end{array}$} & \multicolumn{13}{|c|}{ lat } & \multirow{2}{*}{\multicolumn{5}{|c|}{$\begin{array}{l}\text { Ind } \\
\text { deposit - uppermost part }\end{array}$}} \\
\hline & \multicolumn{3}{|c|}{ BL 8} & \multicolumn{3}{|c|}{$\mathrm{BL}^{\circ}+$} & \multicolumn{3}{|c|}{ Bl: 5} & \multirow{2}{*}{ BI: 6} & \multicolumn{2}{|c|}{$\mathrm{BC} 9$} & \multirow{2}{*}{$\frac{B L \cdot 15}{9 !}$} & & & & & \\
\hline & 3 & 20 & 33 & 37 & 4.3 & 49 & 8 & 19 & 26 & & 84 & 101 & & 22 & 23 & 24 & 25 & 26 \\
\hline $\mathrm{SiO}_{2}$ & +9.90 & $+8.2+$ & +1.65 & $50(1)$ & 52.17 & 53.34 & 6لـ.آ: & -48.83 & .46 .20 & $4+.78$ & 51.92 & 51.82 & +5.1 .4 & 50.67 & 48.19 & 51.12 &.+9.93 & $5(0.64$ \\
\hline $\mathrm{TiO}_{2}$ & 1.14 & 1.81 & 0.95 & 1.61 & 0.68 & 1.08 & 2.01 & 2.06 & 2.40 & 1.01 & 0.66 & 1.39 & 1.01 & 2.69 & 2.1 .3 & 1.95 & 2.84 & 2.3() \\
\hline $\mathrm{Al}_{2} \mathrm{O}_{3}$ & 8.05 & 6.72 & 6.01 & 7.90 & 11.05 & 8.95 & 3.95 & +.77 & 4.76 & 10.77 & 7.16 & 5.44 & 5.0 .4 & 3.63 & $3 .+0)$ & $+6 t$ & 3.52 & 3.60 \\
\hline $\mathrm{Fc}_{2} \mathrm{O}_{3}$ & 12.26 & 17.64 & 12.42 & 16.63 & 9.63 & 12.27 & 21.00 & 19.2 .4 & 18.46 & 15.83 & $12 .+2$ & 19.74 & 15.33 & 23.08 & 21.08 & 19.26 & 22.04 & 23.25 \\
\hline $\mathrm{MnO}$ & 0.32 & 0.32 & 0.37 & $0 .+5$ & 0.13 & 0.26 & 0.36 & 0.23 & 0.20 & 0.36 & 0.06 & 0.19 & 0.05 & 1.25 & $0.7+$ & 0.52 & 0.97 & 1.09 \\
\hline $\mathrm{MgO}$ & 2.011 & 2.16 & 1.67 & 215 & 2.94 & 2.36 & 3.22 & 3.47 & 3.65 & 11.66 & +.00 & 2.81 & 2.99 & 1.96 & $2.4+4$ & 2.38 & 1.90 & 2.20 \\
\hline $\mathrm{CaO}$ & 0.51 & 0.41 & 0.69 & 0.27 & 1.00 & $0.6+$ & $0.2+$ & 0.67 & 0.22 & 0.56 & 0.19 & 0.32 & 0.23 & 0.23 & 0.2 .3 & 0.63 & 0.35 & (0.20) \\
\hline $\mathrm{Na}_{2} \mathrm{O}$ & 0.32 & 0.05 & 0.15 & 0 & 0.08 & 0.04 & 0.02 & 0.05 & 0 & 0.13 & 0.03 & 0.01 & 0.18 & 0.03 & $0.06 \mathrm{i}$ & 0.12 & 0.05 & 0 \\
\hline $\mathrm{K}_{2} \mathrm{O}$ & 6.32 & 7.63 & 0.4 .3 & 7.19 & 5.24 & 6.46 & 7.99 & 7.97 & 7.69 & 5.10 & 7.64 & 8.51 & 6.19 & 7.17 & 6.39 & 6.60 & 6.70 & 7.13 \\
\hline Total & 80.8 .7 & 84.98 & 7.3 .34 & 80.25 & 81.92 & 85.34 & 69.25 & 87.29 & 83.58 & 90.20 & 80.08 & 90.23 & 76.16 & 90.71 & $8+66$ & 87.22 & 88.30 & $90 .+46$ \\
\hline $\mathrm{Si}$ & 3.985 & 3.79 .4 & 3.987 & 3.831 & $3.96+$ & $+.00) . t$ & $3.8+8$ & 3.779 & 3.736 & 3.291 & +0002 & .3 .857 & 3.91 .3 & 3.798 & $3.8-40$ & 3902 & 3.825 & 3.808 \\
\hline $\mathrm{Ti}$ & 0.068 & 0.107 & 0.064 & 0.093 & 0.0 .39 & 0.061 & 0.113 & 0.120 & $0.1+6$ & 0.056 & 0.0 .38 & 0.078 & 0.066 & 0.152 & 0.128 & 0.112 & $0.16 .+t$ & (0.130) \\
\hline$\left.A\right|_{t u !}$ & 0.758 & 0.623 & 0.6 .33 & 0.713 & 0.990 & 0.792 & $0.3+8$ & $0 .+3.5$ & 0.454 & 0.9 .33 & 0.650 & 0.477 & 0.515 & 0.321 & 0.319 & $0 .+17$ & 0.318 & 0.319 \\
\hline $\mathrm{Fc}^{3-}$ & 0.737 & $1.0 .+4 t$ & 0.8 .35 & 0.958 & 0.551 & 0.693 & 1.182 & 1.120 & 1.123 & 0.876 & $0.72+$ & 1.106 & 1.000 & 1.302 & 1.26 .4 & 1.106 & 1.271 & 1.314 \\
\hline $\mathrm{Mn}$ & 0.022 & 0.021 & 0.028 & 0.024 & 0.008 & 0.017 & 0.023 & 0.015 & $0.01 .+t$ & 0.022 & 0.004 & 0.120 & 0.004 & 0.079 & 0.05 & $0.0 .3-1$ & 0.063 & 0.069 \\
\hline $\mathrm{Mg}$ & 0.2 .39 & 0.253 & 0.222 & $0.2+5$ & 0.333 & ().26-1. & 0.359 & 0.400 & $(0 .++40)$ & 1.278 & 0.460 & 0.312 & 0.386 & 0.219 & 0.29 & 0.271 & 0.217 & $0.2+6$ \\
\hline $\mathrm{C}_{\mathrm{il}}$ & 0.044 & 0.0 .35 & 0.066 & 0.022 & 0.081 & 0.051 & 0.019 & 0.056 & 0.019 & $0.04+$ & 0.016 & 0.026 & 0.021 & 0.018 & 0.02 & 0.052 & $0 .(129$ & 0.016 \\
\hline$\therefore a$ & 0.05() & $0.00 \mathrm{~s}$ & 0.026 & () & 0.012 & 0.006 & 0.0013 & 0.008 & () & 0.019 & $0.00+$ & 0.001 & $0 .(0.30$ & $0.0(14$ & $0.0(0) 9$ & 0.018 & 0,007 & () \\
\hline K & 0.644 & 0.766 & 0.733 & 0.702 & 0.508 & 0.613 & 0.762 & 0.787 & 0.793 & 0.478 & 0.751 & 0.808 & 0.685 & 0.686 & 0.6 .50 & $0.6+3$ & 0.655 & 0.683 \\
\hline${ }^{* A I}$ & 0.015 & 0.206 & 0.013 & 0.169 & 0.036 & 0 & 0.152 & (0.221 & $0.26-t$ & 0.709 & 0 & $0.1+3$ & 0.087 & $0.2(1) 2$ & 0.160 & 0.098 & 0.175 & 0.192 \\
\hline Charge IV & -0.015 & -0.206 & -0.013 & -0.169 & -0.036 & 0.016 & -0.152 & -0.221 & $-(0.26-t$ & $-0.7(1) 9$ & 0.008 & -0.14 .3 & -0.087 & $-0.2(1)(0)$ & $-(0.160)$ & -0.098 & -0.175 & -0.192 \\
\hline Charge VI & -0.766 & $-0.6+1$ & -0.874 & $-0.57-4$ & $-0.6+7$ & -0.7 .39 & -0.650 & -0.688 & -0.569 & $0.12+$ & -0.798 & -0.720 & -0.672 & -0.528 & -0.539 & -0.667 & $-0.5 .+2$ & -0.527 \\
\hline Charge interl cat. & 0.782 & $0.8+4$ & $(0.891$ & 0.746 & 0.682 & 0.721 & 0.803 & 0.907 & 0.831 & 0.58 .5 & 0.787 & 0.861 & 0.756 & 0.726 & 0.679 & 0.76 .5 & 0.720 & 0.715 \\
\hline Total charge & 0.001 & 0 & 0 & 0.003 & 0 & () & 0.001 & () & () & 0 & 0 & 0 & -0.003 & () & -0.020 & 0 & 0.003 & () \\
\hline
\end{tabular}

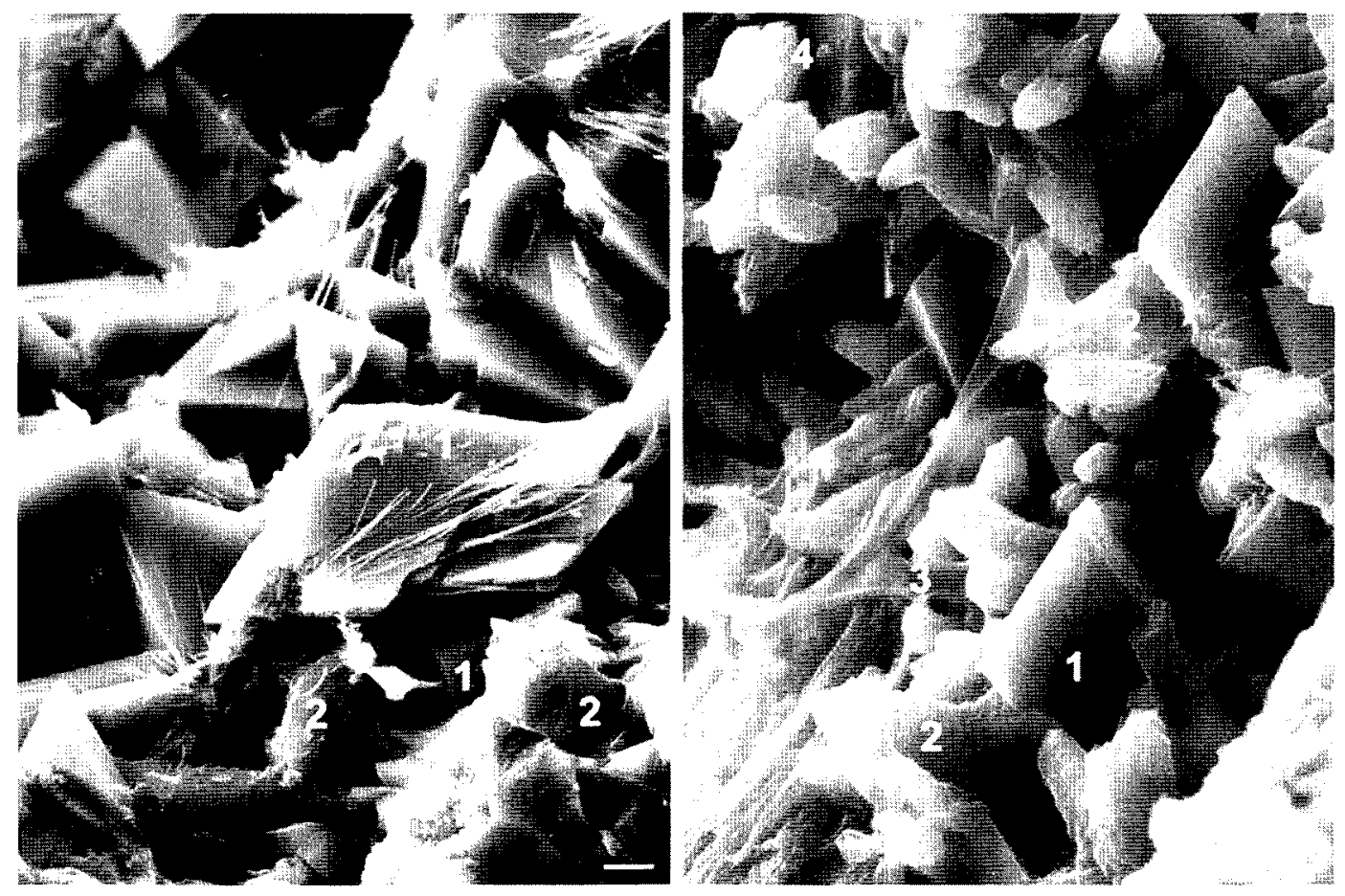

Fig. 10. SEM images from samples of the pumice rich upper part of the first pyroclastic flow (1st acid volcanic phase. see Fig. 2 for sample location): left, adularia crystals (1) with mordenite needles and platy clinoptilolite crystals (2) in an altered pumice clasts: right. adularia (1). clinoptilolite platy crystals (2). mordenite skeleton crystals (3) and celadonite (4) in the altered matrix of the pyroclastics. The scale bar corresponds to $10 \mu \mathrm{m}$. 


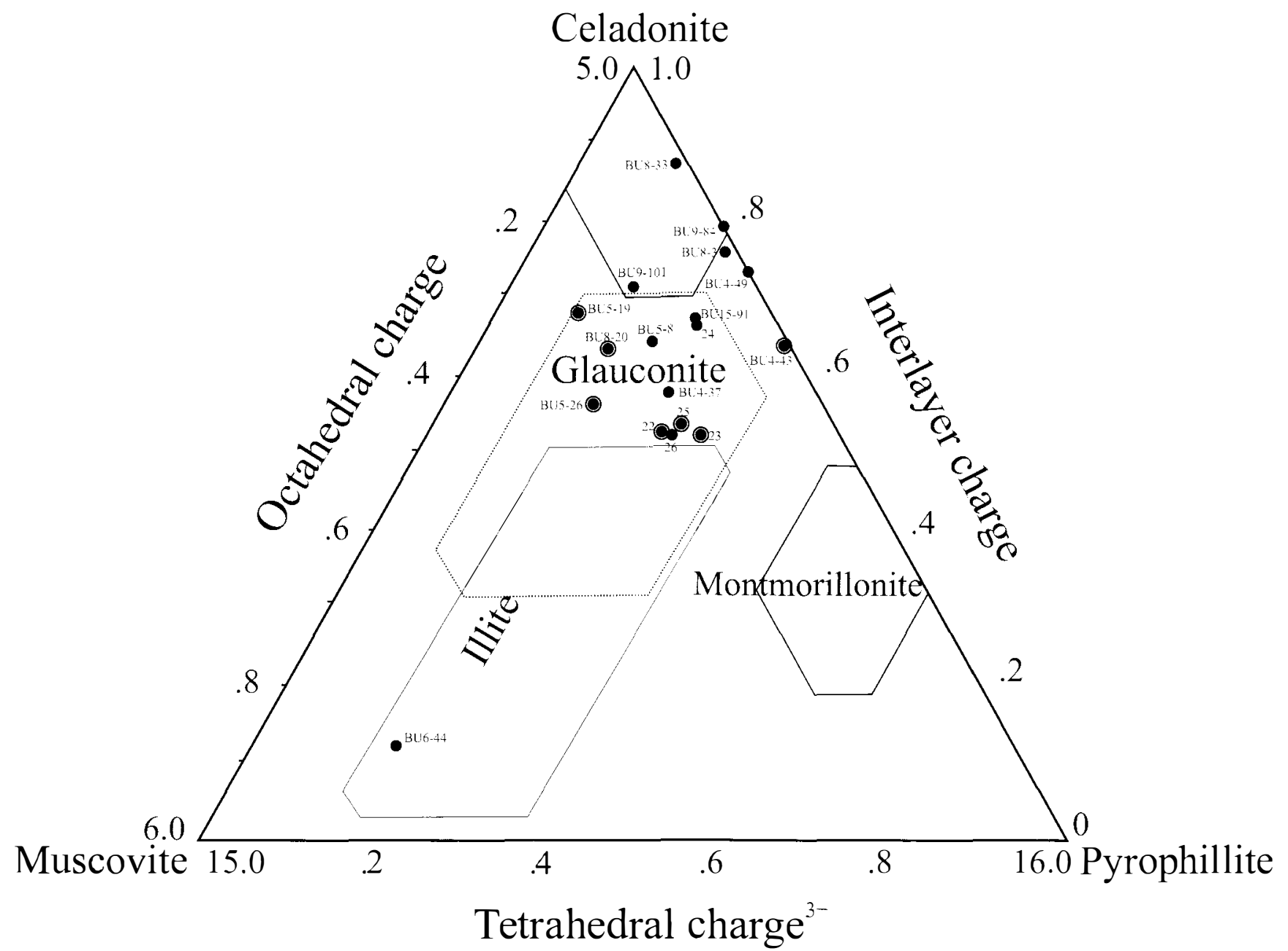

Fig. 11. Chemical composition of phyllosilicates in the \%eolitized pyroclastics of the 1st and 2nd phases. expressed as cndmembers muscovite-celadonite-pyrophyllite (Yont:R \& Eugster 1955: composition fields are after KösTER 1982). Double circles: glauconite according to the criteria defined by the AIPEA Nomenclature Committee (BAll.IY 1980): ${ }^{1 \mathrm{~V}} \mathrm{Al}$ (or ${ }^{\prime \prime} \mathrm{Fe}^{3+},>0.2 .{ }^{1} \mathrm{R}^{3-}>1.2$ and Fe ${ }^{3+}>>\mathrm{Al}$. For sample location see Fig. ?.

deposit) varies from 40 to $153 \pm 5 \mathrm{meq} / 100 \mathrm{~g}$. The highest value has been measured in the fine ash fall-out tuffs from the medial zone (BU 14 from Chiflik outcrop. 2nd phase). The zeolitized fall-out tuff's of Beli Plast deposit (1st phase) have a similar CEC ( $140 \mathrm{meq} / \mathrm{l00 \textrm {g } )}$ that is in accordance with the published values of other economically recognized deposits (RAYNov et al. 1997). The lowest CEC has been detected in sample BU 5 from an epiclastic bed containing a large amount of lithic fragments.

The CEC depends significantly on the quantity of zeolites but also by the presence of other mineral phases. e. g. clays. The reference clay sample has $128 \mathrm{meq} / 100 \mathrm{~g}$. Low. but significant positive correlation between the CEC values and the amount of clinoptilolite determined by $\mathrm{X}$-ray diffraction is evident $(\mathrm{r}=0.58$ : the level of sig- nificance for 14 samples is $\left.|\mathrm{r}|_{(0.0)} \geq 0.537\right)$. The correlation coefficient between CEC and zeolite quantity obtained by the heat of immersion method of Culfaz et al. (1973) is $r=0.71$.

\section{Discussion}

\section{Vertical and lateral distribution of the glass replacing minerals}

Reported details on the overall distribution of the glass replacing minerals are based on authors field and laboratory studies on an area of ca. $450 \mathrm{~km}^{2}$ in the Eastern Rhodopes volcanic area completed by the already published data about the alteration of the pyroclastics, of the 


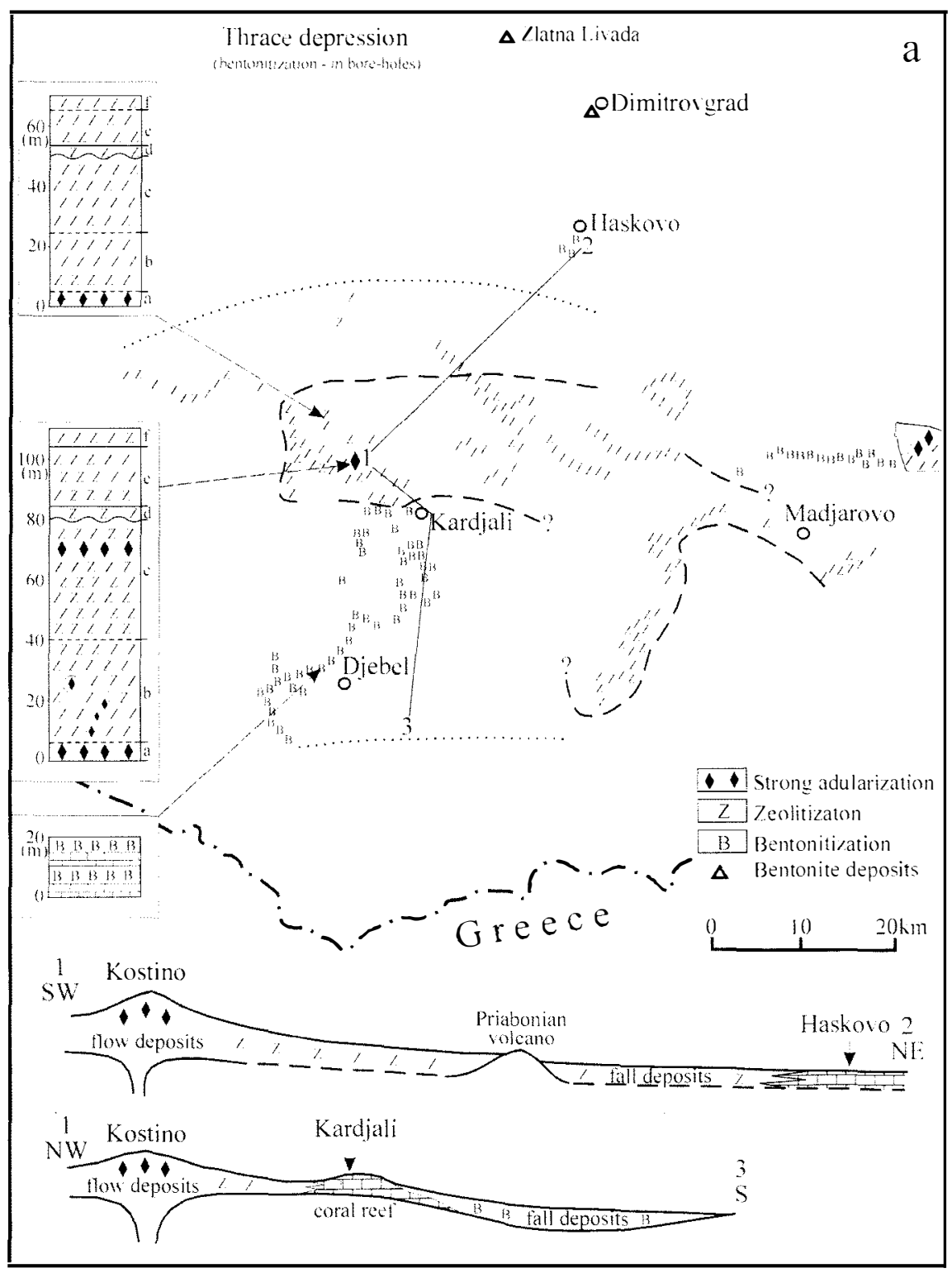

Fig. 12. Sketch maps showing the lateral zoning in distribution of alteration products identified in the pyroclastics of the 1 st (a) and 2 nd (b) Early Oligocene acid phases; the areas of pyroclastic flows deposits and fall-out tuffs are limited by dashed and dotted lines, respectively ( $\mathrm{D}$, Dambalak and M, Madjarovo latite volcanoes, immerged during the 2 nd acid phase). The lines 1-2, 1-3 and 4-5 indicate locations of the schematic cross-sections at the bottom (not to scale). Insets show simplified lithologic sections from different deposition zones with the vertical distribution of the glass replacing minerals (a. b. c. d. e and f refer to the lithologic units. Fig. 2).

1st and 2nd Early Oligocene acid volcanic phases. Both vertical and lateral zoning has been established summarizing all available data on the spatial distribution of the secondary mineral associations (Fig. 12).

Vertical zoning. Volcanic glass from the basal layers of the proximal and medial pyroclastic deposits erupted from Kostino volcanic centre (lst phase) is always replaced by adularia + quartz $(+$ analcime in the area of Most deposit, Duøurova 1976). All available data (pre- sent study, Aleksiev et al. 1997. R aynov et al. 1997 and the references therein) show that clinoptilolite, accompanied by opal-CT, celadonite-glauconite or/and mixedlayered celadonite-smectite. largely prevails in the rest of the section. In the Sheinovets caldera fill deposits, also belonging to the 1st volcanic phase. adularia ( \pm opal CT) is prevailing in the lowermost parts of the section, mordenite and clinoptilolite in the middle and upper parts, respectively (IvanOVA et al. 2001). 


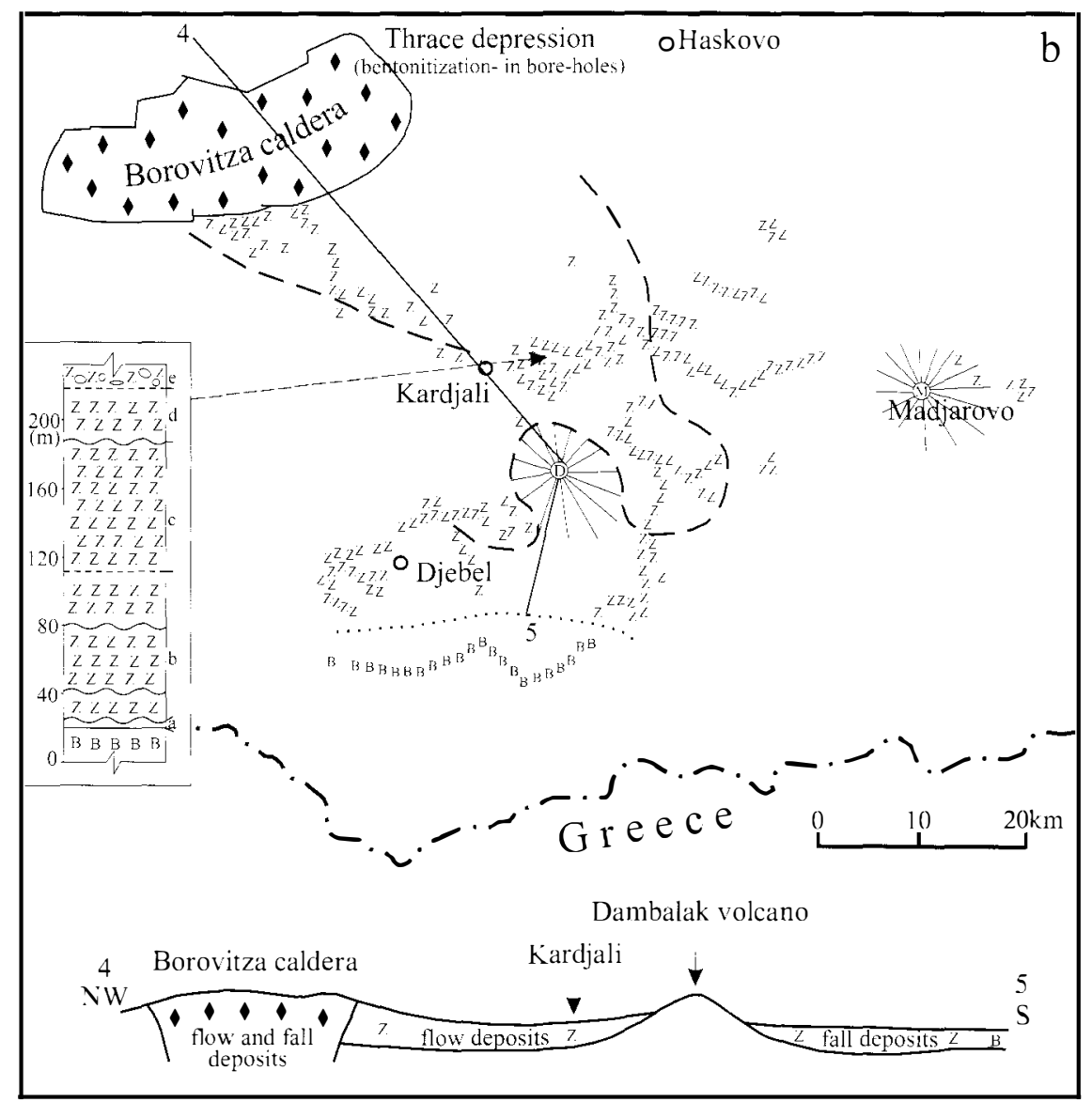

Fig. 12 b.

The existence of vertical zoning in the distribution of the extra framework cations in clinoptilolite from the 1st phase pyroclastic section is reported by ALEKSIEV \& Djourova (1982) and Djourova \& Ivchinova (1987) based on their studies in Moriantzi. Beli Plast and Kostino. According to these authors $\mathrm{Na}$ decreases upward. $\mathrm{K}$ increases in the same direction. and $\mathrm{Ca}$ concentrates in the middle or upper parts of the section. An increase of $\mathrm{K}$ content in clinoptilolite towards the upper parts of the pyroclastic sequence is also detected in the Sheinovets caldera (IVANOVA 2002).

We have also found zoning in the distribution of the extra framework cations in the Belia Bair deposit but in the opposite direction: $\mathrm{Na}$ increases and $\mathrm{K}$ decreases to the top of the section (Fig. 9. Table 4).

Lateral zoning in the distribution of glass replacing minerals has been also established in the Eastern Rhodopes zeolitized pyroclastics. Close to Kostino - the vent area of the 1st phase (Shabandere section) adularia, accompanied by clinoptilolite and/or mordenite, locally predominates (e. g. in the pumice-rich upper part of the first zeolitized flow: Figs. 3 and 10). In the proximal area of the 2nd phase (Borovitza caldera) the pyroclastic materials. some $\mathrm{km}$ thick. is entirely replaced by adularia, clay minerals and quartz without any zeolites (YANEV 1990). In the medial area of both phases. pyroclastic rocks are completely zeolitized and adularia is rarely found. In the distal areas. the pyroclastic rocks are bentonitized: e. g. in the Djebel depression (Boyanov \& GoRANOV 2001) and the Zlatna Livada bentonite deposit in the Trace depression (Atanasov et al. 1965), all belonging to the 1 st phase.

\section{On the origin of the zeolitization in the Eastern Rhodopes}

Several genetic models have been invoked to explain the widespread zeolitization of the Eastern Rhodopes pyroclastic rocks. KIROv (1974) argued that clinoptilolite was formed by reaction of rhyolitic glass with meteoric and groundwater according to the model of HAY (1966). 
Later, a geoautoclave concept was introduced (ALEKSIEV \& Diourova 1975. Aleksiev et al. 1997. Polgari et al. 1997) stating that the zeolitization occurs immediately after the submarine deposition of hot pyroclastic flows rapidly buried by overlying deposits. Autoclave conditions are then created inside the flow units and at the existing pressure, temperature and fluid content the volcanic glass is transforming into zeolites. This hypothesis does not explain the zeolitization of the fall-out tuffs as well as the matrix of the epiclastic layers. The high temperature of the pyroclastic flows $\left(600-700{ }^{\circ} \mathrm{C}\right.$. CAS \& Wright 1995), the low amount of water carried by the flow and dissolved in the glass fragments with regard to the water needed for zeolite crystallization exclude this hypothesis (Raynov et al. 1997, Hall 1997). The last author argues also that the fluids in the pyroclastic flow are strongly acid while the zeolites can be formed under neutral to alkaline conditions only. According to GoTTARDI \& GALLI (1985) this hypothesis concerns only the submarine pyroclastic flow deposits that were cooled by mixing with meteoric and marine water. This specific homogenous hydrothermal environment results in zeolitizaton but can not be called geoauthoclave (HALL 1997).

According to Tsitsishvili et al. (1992) and RaYNov et al. (1997) the zeolitization of the Eastern Rhodopes pyroclastic sequences was caused by regional low-temperature hydrothermal systems. SHEPPARD \& HAY (2001) pointed out that the zeolites from Southeastern Europe are an example of formation in an open hydrologic system but in marine environment. whereas UTADA (2001) considered them as result of burial diagenesis.

Aleksiev \& Djourova (1975) were the first to indicate that all zeolitized Eastern Rhodopes pyroclastics are submarine deposits. This observation is strongly supported by our data: the lst phase pyroclastics overlie Priabonian marine sediments and coral reefs; the topmost part of the 2nd phase section includes (see Fig. 2) and is covered by biogenic limestone: in both phases microfossils are present in the pyroclastics (see Table 1) and ripple marks in some fall-out tuffs of the 2nd phase (Jelezni Vrata quarry, Chiflik outcrop). There are no indications of subaeral deposition of zeolitized rock: neither accretionary lapillis nor zeolitized strongly welded ignimbrites (with fiamme) are known. On the slopes and the top of the latite Dambalak and Madjarovo volcanoes. south-east of Kardjali (Fig. 12), the acid pyroclastics with accretionary lapillis are probably deposited in subaerial environment, but they are not zeolitized. The some $\mathrm{km}$ thick strongly welded ignimbrites filling in the Borovitza caldera are not zeolitized as well (YANEV 1990). On the contrary, not all pyroclastics deposited in marine environment are zeolitized, especially those building the vol- canic edifices (e. g. the lowest part of the Borovitza rhyolitic section. YaneV 1990, or the Priabonian Lozen volcano. YANFV et al. 1975). HaLl (1997) explains this by the acid environment existing in the volcanic edifices close to the vent areas.

Most of the features of zeolitized pyroclastics from Eastern Rhodopes are indicative of burial diagenesis (according to the criteria of GOT'TARDI 1989): low temperature $\left(<200{ }^{\circ} \mathrm{C}\right)$ authigenic minerals, presence of one or two zeolite minerals only over large areas. small crystal size. vertical zoning in the distribution of the glass replacing minerals with thick (many tens of meters) mineral zones. According to Imsma (1988) the temperature of burial glass transformation into clinoptilolite and/or mordenite in the Neogene Green Tuff region of Japan is 41$55^{\circ} \mathrm{C}$. However, the lack or the small thickness of the glass-zeolite transition zone and the short time span of zeolitic alteration (see below) are different from the products of burial diagenesis (according to the critera of HAY \& SHEPPARD 2001). Whereas the observed vertical zoning (adularia at the base of the 1st phase pyroclastics) could be explained by the depth depending burial diagenesis, the lateral zoning suggests a hydrothermal genesis. The lateral zoning is evident as strong adularization in the proximal zones. Kostino area and Borovitza caldera. formed at relatively high temperature and/or high activity of $\mathrm{K}$ : zeolitization in the medial zone in the confines of the region of volcanic activity; bentonitization out of it. in the distal zone (Fig. 12). The wide distribution of celadonite within the zeolitized pyroclastics especially in the 1st phase may also indicate a hydrothermal origin. The celadonite is one of the most precisely documented cases of authigenic clay formation from the hydrothermal areas in mid-oceanic ridges (HILLIER 1995). Under hydrothermal conditions the temperature of zeolite genesis is higher than during the burial diagenesis: the maximal temperature of clinoptilolite formation is $150-250{ }^{\circ} \mathrm{C}$ (BARTH-Wirsching \& Höller 1989); the temperature of mordenite formation in Wairakei geothermal area is $150-230^{\circ} \mathrm{C}$.

The chemical difference between the unaltered volcanic glass and zeolitized pyroclastics in the Eastern Rhodopes (Fig. 5) argues for an open system, but the classical hydrologic open system (in the sense of HAY \& SHEPPARD 2001) is developed for non marine pyroclastics. altered by meteoric water. The low temperature of this type of alteration demands a very long time of zeolitization of up to $10 \mathrm{Ma}$ for thick pyroclastic series (Tschenich 1992). The Paleogene Eastern Rhodopes pyroclastics are deposited in a marine environment as their zeolitization has not taken very long time presuming that the zeolitized products of the two acid phases are sepa- 
rated by non zeolitized but bentonitized latitic tuffs: the total duration of all Early Oligocene phases is not more than 3-4 Ma (Lilov et al. 1987) and the zeolitization has not affected the top of the Lower Oligocene section neither the Upper Oligocene sedimentary cover.

The glass shards may have been replaced by dissolution-reprecipitation processes according to the models of PutNis (2002) with preservation of the shard morphology and formation of the distinct zonality. Dissolution of the shard surface and precipitation of the celadonite/smectite rims (Figs. 4 and 8), resulting in enrichment of $\mathrm{Si}$ and alkalis in the solution (HAY 1966), is the first stage of the glass replacement process. During the second stage the glass from the shards interior continue to dissolve under the influence of the $\mathrm{Si}$ - and alkalienriched solution and high-Si zeolites crystallized, accompanied by different phyllosilicates and opal-CT. This process is similar to the replacement of perlite bodies by zeolites described by YANEV et al. $(1986,1993)$ and NoH $\&$ Boles (1989). In the pumice clasts deposited near to the vent, which are able to retain their initial high temperature for longer time (KAMINSKI \& JAUPART 1997), adularia (or albite) crystallized preferentially.

The zeolitizing hydrothermal solutions consist of marine water heated by the anomalous geothermal gradient of the active volcanic areas or/and by the hot pyroclastic rocks (Lenzi \& Passaglia 1974, GotTardi \& Galli 1985). Even a difference in temperature between volcanic rocks and marine water as big as $30-40{ }^{\circ} \mathrm{C}$ can trigger a hydrothermal circulation (HALL 1997). These solutions percolate throughout the permeable pyroclastic horizons over large areas and zeolitize all glass containing rocks including epiclastics. The participation of the endogenous solutions coming from the magma chambers in this process is notified by some authors (i.e. GogishviLI 1980. GotTardi 1989, Tschenich 1992, Tsitsishvili et al. 1992) but at that stage of our work we can neither support nor decline this hypothesis.

\section{Acknowledgements}

This study was partly supported by the project NZ-1306 of the Bulgarian Scientific Found of the Ministry of Education and Science. The authors wish to thank M.-O. Trensz (CEREGE, France) for the whole-rock chemical analyses and P. LEGGo (University of Cambridge, U. K.) for duplicating the CEC measurements. Tz. ILIEv (Geological Institute, Sofia) and F. Olmi (University of Florence, Italy) are highly acknowledged for the SEM studies and microprobe analyses. We are also much obliged to A. Langella (University of Sannio, Benevento,
Italy), H. Pallick, (University of Bonn, Germany) and an anonymous reviewer for their constructive comments on the paper.

\section{References}

Aleksiev, B. (1968): Clinoptilolite des Rhodopes du nordest. C.-R. Acad. bulg. Sci. 21: 1093-1095.

Al.eksiev. B. \& Duolrova. E. G. (1975): On the origin of zeolite rocks. - C.-R. Acad. bulg. Sci. 28: 517-520.

- - (1982): Zeolitic rocks in the area between the villages Golobradovo and Moriantzi. - Ann. Univ. Sofia, Fac. géol. \& géogr. 76. 1-géol.: 3-15 (in Bulgarian with an Engl. abstr.).

Aleksiev, B., Djolrova. E. \& Milakovska-Vergilova. Z (1997): Geology of the Oligocene zeolitic rocks in NE Rhodopes, Bulgaria: a review and new data. - In: Kirov. G., FiliZova, L. \& Petrov', O. (eds.): Natural Zeolites, Sofia '95 Pensoft. Sofia-Moscow: pp. 249-262.

Aliet11, A.. Brigntti, M. F. \& Poppi, L. (1977): Natural Ca-rich clinoptilolites (heulandites of group 3): new data and review. N. Jb. Miner. Mh. 1977: 493-501.

Atanasov, G.. Goranov, A., Stefanov. D. \& Trashimev, S. (1965): Bentonite clays of the Zlatna Livada, Chirpan region. Ann. Univ. Sofia. Fac. géol. \& géogr. 58. l-géol.: 145-156 (in Bulgarian with an Engl. abstr.)

BAILEY, S. W. (1980): Summary of recommendations of AIPEA nomenclature committee. - Clay Miner. 15: 85-93.

BARTH-WiRSChing, U. \& HöLler. H. (1989): Experimental studies on zeolite formation conditions. - Eur. J. Miner. 1: 489506.

Boyanov, I. \& Goranov. A. (2001): Late Alpine (Paleogene) superimposed depressions in the parts of Southeast Bulgaria. Geologica Balcanica 31 (3-4): 3-36.

CAS, R. A. F. \& Wright. J. V. (1995): Volcanic successions, modern and ancient. - Chapman \& Hall, London.

CHANG, F. (1974): Quantitative interpretation of X-ray diffraction patterns of mixtures. I. Matrix-flushing method for quantitative multi component analysis. - J. Appl. Crystal. 7: 519-525.

- (1975): Quantitative interpretation of X-ray diffraction patterns of mixtures. II. Simultaneous determination of set of reference intensities. - J. Appl. Crystal. 8: 17-19.

Coombs, D. S.. Alberti. A.. Armbruster, T., Artioli, G.. Colei.la. C., Galli, E.. Grice. J. D.. Liebau. F.. Mandarino, J. A.. Minato. H., Nickel. E. H., Passaglia. E., Peacor, D. R.. Quartieri, S.. Rinaldi, R., Ross, M.. Sheppard, R. A.. TillMANNS. E. \& VEZZalini, G. (1997): Recommended nomenclature for zeolite minerals: Report of the subcommittee on zeolites of the IMA. Commission on New Minerals and Mineral Names. - Canad. Mineral. 35: 1571-1606.

Culfaz, A.. Keisling, C. A. \& Sand. L. B. (1973): A field test for molecular sieve zeolites. - Amer. Mineral. 58: 1044-1047.

Diourova. E. G. (1976): Analcime zeolitites from the North-Eastern Rhodopes. - C.-R. Acad. bulg. Sci. 29: 1023-1025.

Duol:Rova, E. G. \& Aleksiev. B. (1990): Zeolitic rocks related to the second acidic Paleogene volcanism to the east of the town of Kardjali. - In: Konstantinos, S. (ed.): Geologica Rhodopica, 2, Aristotl University. Thessaloniki: pp. 279-489. 
Duourova. E. \& Ivchinova. L. (1987): Distribution of K. Na. Rb and $\mathrm{Ca}$ in the clinoptilolitic rocks of some zeolitic deposits in the North-Eastern Rhodope. - Ann. Univ. Sofia. Fac. géol. \& géogr. 81, l-géol.: 75 -89 (in Bulgarian with an Engl. abstr.).

GogishviLI, V. G. (1980): Epigenetic character of stratified deposits of highly siliceous zeolites (on example of the Transcaucasus). - In: Kossovskaya, A. G. (ed.): Prirodnie Tzeoliti (Natural Zeolites), Nauka Ed. House, Moscow: pp. 65-75 (in Russian).

Got TARDI, G. (1989): The genesis of zeolites. - Eur. J. Miner. 1: 479-487.

Gottardi, G. \& Galli. E. (1985): Natural Zeolites. Springer, Berlin.

HALL, A. (1997): Large eruptions and large zeolite deposits. - In: Zeolite'97, 5th International Conference on the Occurrence. Properties, and Utilization of Natural Zeolites. Ischia. Italy. Program with Abstracts. A. De Frede, Naples: pp. 26-28.

HAY, R. L. (1966): Zeolites and Zeolitic Reactions in Sedimentary Rocks. - Geol. Soc. of America. Spec. Paper 85.

HAY, R. L. \& Sheppard, R. A. (2001): Occurrence of zeolites in sedimentary rocks. - In: Bish. D. L. \& MiNG, D. W. (eds.): Natural Zeolites: Occurrence, Properties, Applications. Reviews of Mineralogy and Geochemistry 45. Miner. Soc. of America, Geochem. Soc.: pp. 217-234.

Hillier, S. (1995): Erosion, sedimentation and sedimentary origin. - In: Velde, B. (ed.): Origin and Mineralogy of Clays. Springer Verlag. Berlin: pp. 162-219.

IIJImA, A. (1988): Diagenetic transformation of minerals as exemplified by zeolites and silica minerals - a Japanese view. In: Chilingarian, G. V. \& Wolf, K. H. (eds.): Diagenesis II, Developement in Sedimentology 43. Elsevier, Amsterdam: pp. 147-211.

Ivanov, R. (1963): Magmatism in the Eastern Rhodope Paleogene depression. Part II - Petrochemical evolution and provincial peculiarities. - Trudove Geol. Bulg. Seria Geochim.. Miner. \& Petrogr. 4: 297-323 (in Bulgarian with an Engl. abstr.).

Ivanova. R. (2002): Petrology of Acid Volcanic rocks from Sheinovetz caldera, Eastern Rhodopes. - Unpubl. Ph. D. Thesis. Geol. Inst. Sofia (in Bulgarian).

Ivanova, R.. Stoykova, K. \& Yanev. Y. (2000): Acid pyroclastic rocks from the Sheinovets caldera (Eastern Rhodopes): Lithostratigraphy, characteristics and age. - Geochem.. Mineral. \& Petrol., Sofia 37: 95-103.

Ivanova, R., Yanev, Y., Iliev, Tz., Koleva, E.. Popova. T. \& Popov. N. (2001): Mineralogy, chemistry and ion-exchange properties of the zeolitized tuffs from the Sheinovets caldera. Eastern Rhodopes (South Bulgaria). - In: Galarneal; A.. Di Renzo. F. Fajula. F. \& Vedrine, J. (eds): Studies in Surface Science and Catalysis 135. Elsevier, Amsterdam: pp. 95-103.

KAMINSKI, E. \& JAUPART, C. (1997): The expansion and quenching of vesicular magma fragments in plinian eruptions. - J. Geophys. Res. 102: 12187-12203.

KIROv. G. (1974): Zeolites in sedimentary rocks from Bulgaria. Ann. Univ. Sofia, Fac. géol. \& géogr. 66. 1-géol.: 171-184 (in Bulgarian with an Engl. abstr.).

Kitsopoulos, K. (1999): Cation-exchange capacity (CEC) of zeolitic volcaniclastic materials: applicability of the ammonium acetate saturation (AMAS) method. - Clays \& Clay Miner. 47: 688-696.
Köster. H. M. (1982): The crystal structure of 2:1 layer silicates. - In: Van Olphen. H. \& Veniale. F. (eds.): Development in Sedimentology. Proceed. Intern. Clay Conf. Bologna/Pavia. Elsevier. Amsterdam: pp. 41-71.

Lenzi. G. \& Passaglia. E. (1974): Fenomeni di zeolitizzazione nelle formazioni vulcaniche della Regione Sabatina. - Boll. Soc. Geol. Ital. 93: 623-645.

Lilov. P., Yanev, Y. \& Marchev. P. (1987): K/Ar dating of the Eastern Rhodopes Paleogene magmatism. - Geologica Balcanica 17 (4): 49-58.

McPhie, J., Doyle. M. \& Al.len. R. (1993): Volcanic Textures. University of Tasmania.

Minato, H. (1997): Standardization of methods for zeolite specialty determination and techniques for zeolite resources utilization. - In: Kirov. G.. Filizova. L. \& Petrov. O. (eds): Natural Zeolites, Sofia'95, Pensof t. Sofia-Moscow: pp. 282-292.

NoH, J. H. \& Boles, J. R. (1989): Diagenetic alteration of perlite in the Guryongpo area. Rep. of Korea. - Clays \& Clay Miner. 37: 47-58.

Passaglia. E. (1970): The crystal chemistry of chabazites. - Amer. Mineral. 55: 1278-1301.

Peter. E. \& Kalman. A. (1964): Quantitative X-ray analysis of crystalline multicomponent systems. - Acta Chimica Hungarica 41: $413-422$.

Polgari, M.. Forizs. I.. Mathe. Z.. Toth. M. \& Pecsi-Donath, E. (1997): Geoautoclave-type zeolitization in the Miocene rhyolite tuff, Mecsek Mts.. SW Hungary. - In: KIrov, G., Filizova, L. \& Petrov. O. (eds.): Natural Zeolites, Sofia'95, Pensoft, Sofia-Moscow: pp. 227-2.40.

PUINIS, A. (2002): Mineral replacement reactions: from macroscopic observations to microscopic mechanisms. - Mineral. Mag. 66: 689-708.

Raynov. N., Popov. N., Yanev, Y., Petrova, P., Popova, T., Hristova. V.. Atanasova, R. \& Zankarska, R. (1997): Geological, mineralogical and technological characteristics of zeolitized (clinoptilolitized) tuffs deposits in the Eastern Rhodopes. Bulgaria. - In: Kirov, G., Filizova. L. \& Petrov, O. (eds.): Natural Zeolites, Sofia '95, Pensoft. Sofia-Moscow: pp. 263275.

Ricol, L.-E. (1994): Tethys reconstructed: plates, continental fragments and their boundaries since 260 Ma from Central America to Southeastern Asia. - Geodinam. Acta 7: 169-218.

SHEPPARD, R. A. \& HAY, R. L. (2001): Formation of zeolites in open hydrologic systems. - In: BISH. D. L. \& MING, D. W. (eds.): Natural Zeolites: Occurrence, Properties. Applications. Reviews of Mineralogy and Geochemistry 45. Miner. Soc. of America. Geochem. Soc.: pp. 261-275.

Thieblaiont. D. \& Tegyey, M. (1994): Une discrimination géochimique des roches différenciées témoin de la diversité d'origine et de situation tectonique des magmas calco-alcalines. C.-R. Acad. Sci. Paris 319, série II: 87-94.

Tschenich. R. W. (1992): Zeolites of the World. - Phoenix Geosci. Press. Inc.

Tsitsishvili, G. V., Andronikashvili. T. G.. Kirov. G. N. \& FiLizova, L. D. (1992): Natural Zeolites. Ellis Horwood, Chichester.

UTADA. M. (2001): Zeolites in burial diagenesis and low-grade metamorphic rocks. - In: Bish. D. L. \& Ming. D. W. (eds.): Natural Zeolites: Occurrence. Properties. Applications. Reviews of Mineralogy and Geochemistry 45. Mineral. Soc. of America, Geochem. Soc.: pp. 277-304. 
Yanev, Y. (1990): Evolution of the Acid Volcanism of the Borovitza Caldera and its Frames. - Unpubl. Habil. Thesis. Geol. Inst., Sof ia (in Bulgarian).

- (1995): General characteristics of the Late Paleogene collision volcanism in the Rhodopes. - In: Aleksiev, B. (ed.): Guide to the Post-meeting Field Trip. Sof ia Zeolite Meeting '95 pp. 3-19.

- (1998): Petrology of the Eastern Rhodopes Paleogene acid volcanics, Bulgaria. - Acta Vulcanol. 10(2): 265 - 277.

YANEV, Y. \& BAhNeva. D. (1980): Alpine magmatism in the Carpathian-Balkan area in plate-tectonic models. - In: NACHEV, I. \& Ivanov, R. (eds.): Geodinamika na Balkanite (Geodynamic of the Balkans) Technika Publ. House, Sofia: pp.63-75 (in Bulgarian).

YANEV, Y. \& BARDinTZEFF, J.-M. (1996): Dynamismes éruptifs du volcanisme paléogène de collision des Rhodopes orientaux (Bulgarie). - C.-R. Acad. Sci. Paris 322, série Ila: 437-444.

Yanev, Y., Raynov, N., Tchechlarova. I., Tchuneva, V., MaTANOVA, M. \& LaZAROVA. V. (1986): Zeolites in perlites from the eastern part of the Borovitza region, Eastern Rhodopes (Bulgaria). - In: Crystal Chemistry of Minerals. Proc. of 13th General Meeting of the IMA, Varna, 1982. Sofia, Publ. House Bulg. Acad. Sci.: 737- 748 .
Yanev, Y., Harkovska. A., Mavroudchiev, B.. Velchev, Tz., No.jarov, P. \& Damianov. D. (1975): Lozen Paleogene volcano and its relationship with the deep structure. - Geochim.. Miner. \& Petrol., Sofia 2: 90-101 (in Russian with an Engl. abstr.).

Yanev, Y., Ildefonse. Ph. \& Stefanov, D. (1993): Chemical characterization of clay minerals associated with zeolitization of perlites (East Rhodopes, Bulgaria). - Geol. Carpathica, Series Clays 44 (1): 35-42.

Yanev, Y.. Innocenti, F., Manetti, P. \& Serri, G. (1998): Upper Eocene-Oligocene collision-related volcanism in Eastern Rhodopes (Bulgaria) - Western Thrace (Greece): Petrogenetic affinity and geodynamic significance. - Acta Vulcanol. 10 (2): 279-291.

Yanev, Y., Ivanova. R. \& ILIEv, Tz. (2004): Zeolite deposit "Jelesni Vrata" ("Iron Door"). - In: Guerrieri, L., Rischia, E. \& Serva, L. (eds.): 32nd Internat. Geol. Congress. Florence, Italy, August 20-28, 2004. P 36 Post-Congress excursion "Paleogene and Recent Volcanism in the Eastern Rhodopes (Bulgaria) and on Milos Island (Greece). and Related Industrial Minerals", pp. 7-14.

Yoder H. S. \& Eugster H. P. (1955): Synthetic and natural muscovites. - Geochim. \& Cosmochim. Acta 8: 225-280.

\section{Author's addresses:}

Yotzo Yanev, Rossitza Ivanova, Rita Pravchanska. Geological Institute, Bulgarian Academy of Science. Acad. G. Bončev str., bl. 24, Sofia 1113, Bulgaria. E-mail: yotzo@geology.bas.bg

Jean-Jaceues Cochemé. Emantelle Burlet, Université Aix-Marseille, Faculté des Sciences de St Jérôme, Laboratoire de Pétrologie Magmatique, Case 441, 13397 Marseille Cedex 20. France. E-mail: jean-jacques.cocheme@univ.u-3 mrs.fr Olivier Grauby, CRMC2-CNRS, Campus de Luminy, Case 913. 163 avenue de Luminy, 13288 Marseille Cedex 9. France. 